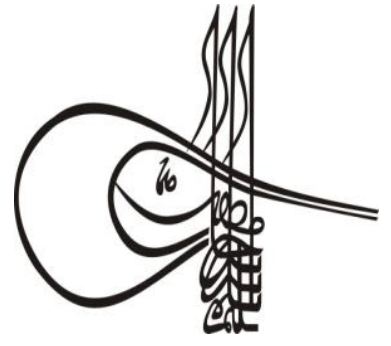

Turkigh Studies
CUDES 2019

Volume 14 Issue 5, 2019, p. 253-276

DOI: 10.29228/TurkishStudies.23010

ISSN: $1308-2140$

Skopje/MACEDONIA-Ankara/TURKEY

Research Article / Araştırma Makalesi

Article Info/Makale Bilgisi

Received/Geliș: 04.05.2019

$\checkmark$ Accepted/Kabul: 10.08.2019

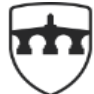

INTERNATIONAL BALKAN UNIVERSITY

EXCELLENCE FOR THE FUTUR IBU.EDU.MK

Report Dates/Rapor Tarihleri: Referee 1 (24.05.2019)-Referee 2 (24.05..2019)

This article was checked by iThenticate.

\title{
KILIÇZADE HAKKI'NIN YAZILARINDA DİN VE LAİKLİK
}

\author{
Esma TORUN ÇELIIK*
}

\begin{abstract}
öz
II. Meşrutiyet dönemi düşün akımlarından Batıcılık, Osmanlı Devleti'nin çöküşünü önlemek ve Avrupa devletlerinin gelişmişlik düzeyini yakalamak için, onların geçirdikleri aşamaları geçirmek ve onların maddi ve manevi uygarlığını alma gerekliliğine duyulan inançtan doğmuştu. Temel amacı batılılaşma yoluyla Osmanlı'nın çöküşüne engel olmaktı. Bu görüşü savunanların başında gelen Kılıçzade Hakkı, Batıcı görüşlerin savunulduğu Abdullah Cevdet'in sahibi olduğu İçtihad Dergisi'nde yazım hayatına başlamıștı. Biyolojik materyalizm düşüncesinin etkisi altındadır. Daha ilk yazısı olan "Pek Uyanık Bir Uyku" makalesi büyük yankı bulmuş ve dikkatleri üzerine çekmeyi başarmıştı. Daha sonraki yazılarında ise, Osmanlı'nın geri kalmışlığını, sahte dervişlerin ve softaların topluma empoze etmeye çalıștıkları dinsel cehalete bağlamıştır. Din ve devletin birbirinden ayrılmasının gerekliliğini ileri sürerek, Arap harfleri yerine Latin harflerinin kabul edilmesi gerektiğini savunmuştur. Savunduğu düşünceler nedeniyle dindar çevrelerin ve İttihat ve Terakki Hükümeti'nin tepkisini çekmiştir. 1923 y1lı başında toplanan İzmit Basın Toplantısı sırasında Mustafa Kemal'e çekinmeden yeni devletin dini olup olmayacağını sormuştur. İstediği yanıtı tam olarak alamamasına rağmen, cumhuriyetin ilanıyla birlikte bir rüya olarak yazdığ pek çok yeniliğin gerçekleşmesinden dolayı oldukça memnun olan Kılıçzade, İzmit'te yayınladığı Hür Fikir gazetesinde; dinin toplumdaki etkisinin kırılması ve laikliğin gerçekleştirilmesini savunmuştur. Sahte softa ve dervişlere karş1 mücadeleyi yaşamının temel amac1 saymıştır. Yazılarının büyük bir kısmı dinin özüne dönülmesini, hurafelerden arındırlmasını; din adına Arap kültürünün benimsenmemesini laikliğin devlet ve toplum yaşamına yerleştirilmesini savunmuştur.
\end{abstract}


Anahtar Kelimler: Kılıçzade Hakkı, batıcılık, laiklik, din, Meşrutiyet

\title{
RELIGION AND LAICISM IN THE WRITINGS OF KILIÇZADE HAKKI
}

\begin{abstract}
Westernism, one of the currents of thought of the II. Constitutional Era, was born from the belief in the necessity to prevent the collapse of the Ottoman Empire and to pass through the stages of the European states in order to achieve their level of development and to adopt their material and spiritual civilization. Its main aim was to prevent the collapse of the Ottoman Empire through westernization. Kılıçzade Hakkı, who is one of the advocates of the view, started his writing career in the İçtihad Journal, owned by Abdullah Cevdet, which defended westernist ideas. He was under the influence of the idea of biological materialism. His first article "Pek Uyanık Bir Uyku" [A Sleep Very Awake] had attracted attention. In his later writings, he attributed the backwardness of the Ottoman Empire to the religious ignorance that the dervishes and religious fanatics were trying to impose on society. Asserting the necessity to separate religion and state, he argued that Latin letters should be accepted instead of Arabic letters. Because of his ideas, he got reaction from the religious circles and the Committee of Union and Progress. He openly asked Mustafa Kemal whether the new state would have a religion in İzmit Press Conference held at the beginning of 1923. Although he could not get the answer he exactly wanted, Klliçzade, who was very pleased that many innovations he wrote as a dream came true with the proclamation of the republic, advocated the diminishing effect of religion on society and the realization of secularism in Hür Fikir Newspaper published in İzmit. His main objective in life was to struggle against false religious fanatics and dervishes. In most of his writings, he defended reverting to the essence of religion, freeing of religion from superstition, not adopting the Arab culture in the name of religion, and placing secularism in the context of state and society.
\end{abstract}

\section{STRUCTURED ABSTRACT}

Although his writing career is shorter than the others who defended the idea of Westernism in the II. Constitutional Era, K1liçzade Hakk1 is undoubtedly among the most influential and the most controversial authors due to his ideas with regard to religion. The fact that he spent his childhood years in Manastır was influential in his opinion on Westernism and religion. Although it is frequently seen that those who get military education and join the army as an officer adopt positivism, Kılıçzade Hakkı is one of the few individuals who adopt biological materialism and Darwinism. It is perhaps these philosophical thoughts that have a profound influence in his life.

K1liçzade Hakkı was not known within press until 1912. The fact that he started writing when the first Balkan War was lost could be due 
to the deep trauma of the heavy defeat on the Ottoman intellectual. Since there was no other place to go for the Turks who were exiled from the European land to the central Anatolia, the only solution was to prevent the collapse with radical steps and to turn the state into a modern one. The matter as to how to do this was the mostly asked question by state administrators and intellectuals from the periods of stagnation and regression onwards. Although intellectuals who have adopted the idea of Westernism have not reached a consensus among themselves, they are generally referred to as two groups. Some of them just like moderate Islamists and Turkists- advocated the adoption of material civilization, science, and technology from the West while they argued that spiritual civilization should be preserved as it is since the Islamic world is thought to be superior. This group, whose boundaries cannot be determined sharply, is called moderate westerners. On the other hand, the other group thought that the material and spiritual civilization should be taken as a whole from the West which is constituted of the most developed countries of the age. K1liçzade Hakk1, one of the most important figures of the period, not only defended the afore-mentioned idea through his writings but he also penned the first article "Pek Uyanık Bir Uyku" [A Sleep Very Awake] which is at the same time considered to be the program of Westernism. Therefore, he played an important role in the systematic settling of the Western thought during the constitutional period.

The cognomen Kiliçzade was given to him by the writing staff of İçtihad Journal because of his sharp style. Kilıçzade used it first as a nickname and then as a surname for the rest of his life. The ideas he defended during the II. Constitutional Era as to the need to take the West as a whole were often criticised by an Islamist journal Sebilürreşad and were evaluated as unreasonable being irrelevant to the needs of the society, its cultural context, its religion, and its customs. When viewed as a whole, it is clear that Kiliçzade has a coherent thought. In the revolutions carried out after the proclamation of the republic, many ideas he had advocated were moved into practice.

K1liçzade put his view of the idea of religion on the basis of the idea of Westernization. Much as he frequently states the existence of belief in Allah, he is of the opinion that religion is a human product not based upon a divine source. His view on religion in general and Islam in particular is heavily under the influence of biological materialism, Darwinism and positivism adopted by the many intellectuals of the II. Constitutional Era. That he starts to find a solution to the collapse of the state starting from the individuals is reflected on his views on both Westernization and religion. In fact, his view on religion renders Westernization compulsory and his idea of Westernization plays a decisive role in his view on religion. That is, there is a mutual interaction between his thought on religion and Westernization.

Kılıçzade Hakkı had the biggest struggle against ignorant religious scholars. He even revealed through his articles that he fights against fake religious fanatics and dervishes. His assertions carrying the traces of materialist thinkers and interpreting religion as one of the stages of humanity led to harsh reactions from the conservatives. Although he stated that he has faith in God and that God is omnipotent, he did not believe in what is written about the creation of humankind in the 
sacred books of the four true religions and criticised them. What he wrote about the emergence of religions also drew public attention. Kilıçzade seriously claimed that the prophets formed religions and that religion is not of divine origin.

The subject matter of womanhood had a special place among his writings of the II. Constitutional Era. He is of the opinion that there should be no restrictions for women, religious in particular. Starting from the abolition of hijab, considering the social context of the age, he made radical demands such as that women and men should be equal, that they should be educated together, that women should take part in social life, and that they should choose their marriage partners themselves. As a reason for this, he asserted that the society can be transformed through women.

Because of his articles, journals which he frequently wrote were penalized and shut down. When each publication he made was penalized or each publisher was closed down, he understood the resolution of the Committee of Union and Progress to prevent his production. Klliçzade, in return, was determined to write despite warnings from top executives and lawsuits filed against him. He had an important role in inserting the idea of religious reform and secularism in the agenda of the intellectuals of the country during the II. Constitutional Era.

For Kılıçzade, who was severed from his writing career for a while and worked as a civil servant at the directorate of Muhacirun, it was not possible to stop writing. İzmit, where he went after Çanakkale, was the place he started to write again. It is understood from his writings that Kılıçzade Hakkı, who met Mustafa Kemal in İzmit, starting with the proclamation of the republic, followed with pleasure the innovations which he described as a dream, which he wanted to realize but did not think that they would be realized at all.

K1liçzade, who was congratulated by Süleyman Nazif, found each law and application inadequate and always pointed to the next step until the principle of secularism was fully established in the state and in the social structure. In 1928, when the law on the removal of the article that "the religion of the state is Islam" was accepted, he expressed his happiness and that "this is secularism."

Since with the proclamation of the republic, those who used religion as a means for self-interest was substantially prevented, he did not struggle against this group in his writings. However, in his articles about the Sheikh Sait rebellion, he mentioned the necessity of a total annihilation of such groups arguing that these people would never become republicans and would want to demolish the republic whenever they find the chance. Kiliçzade was opposed to the Directorate of Religious Affairs and the Muftiate, and was against allotting money for these institutions from the budget. According to him, there should be no clergy or religious officials employed by the state because it was against the principle of secularism.

Kılıçzade Hakkı did not fully explain what he understood from secularism in his writings during the II. Constitutional Era but he indicated that religion should be separated from the affairs of the state and that it should not be a point of reference when making laws. He 
emphasized that secularism means freedom of conscience in the Republican era. He anticipated that the state should not interfere with religion just as religion should not interfere with the state. He advocated that no religious institution should be included in the state mechanism. Apart from the fact that he has been subjected to criticism from local or national religious circles, his being sued with many religious insults has also affected these views. He was acquitted of all of these cases.

Since he defended the Quran and worship in Turkish ever since the II. Constitutional Era, he supported the work on this matter. He was of the opinion that if people learn religion in their own language, the ignorant clergymen would not be able to direct them however they wish.

The only issue he does not agree with the republican governments is that the state does not interfere with religion because the government in power also wanted to control and direct religion.

When we compare Kilıçzade Hakkı's views on religion and secularism in two different periods, it is immediately seen that there is consistency in his thought. In spite of pressures and prohibitions, he continued to defend his views fearlessly in the first period. During the Republican period, the notion of administration and law he desired was already present. Although he was criticized by religious circles this time, he did not compromise on his views. Although Hür Fikir is a local newspaper, its impact is national. By opening a local window in Kocaeli, its contribution to the making of a secular state cannot be denied.

Although K1liçzade was the first to write many innovations made by the republic, his dialogue with political power was not taken into consideration. In fact, they are in a distance relationship from the national struggle period onwards. In the 1919 elections, his candidacy from İzmit was not supported. This might stem from the fact that some people who have a Western mind in the period of armistice were in relation with Hürriyet ve İtilaf. His statement that he issued Hür Fikir newspaper because of Mustafa Kemal's desire after the republic shows the interest of those in power in him. Although K1lıçzade Hakk1 was the most enthusiastic advocate of the revolutions from the very beginning, he was not rewarded by the government in power in the same way. He became a member of parliament in 1927 when secularism was substantially put into practice. Political power, known for its radical criticism of the West and religion, might have been afraid of the public reaction at least in the beginning. Although Kıliçzade Hakkı was the originator of many changes related to religion and secularism in the republican period, the fact that he is not often counted among the intellectuals influencing the thought life of the republic may also be the result of this reservation.

Kıliçzade Hakk1 was not fully satisfied with the practices of secularism in the republican era, and he insisted that the state should cut all ties with religion. After he became a member of Parliament from Mus, he closed down the newspaper and moved away from his writing career. We don't know if this is his own volition. However, it is possible to state that his active journalism is over.

Keywords: Kılıçzade Hakkı, Westernism, Laicism, Religion, Constitutionalism. 


\section{Giriş}

Batıcılık düşüncesinin kökleri 18. yüzyılın başlarına kadar gitmektedir. III. Ahmet döneminde askerlik ve toplumsal yaşamda yapılan yenilikler, III. Selim döneminde hız kazanmıştır. Bununla birlikte batılılaşma çalışmaları Tanzimat Fermanı'nın ilanından sonra doruğa ulaşmıştır. 1860'dan sonra ortaya çıkan Yeni Osmanlılar hareketiyle birlikte, Osmanlı'nın kurtuluş çaresinin vazgeçilmez düşüncesi olarak farklı biçimlerde olsa da Batıcılık benimsenmişti. İlk zamanlarda daha tedirgin biçimde ifade edilen Batıcılık, diğer düşünce akımları gibi II. Meşrutiyet döneminde daha sistemli bir akım halinde savunulmaya başlamıştır.

Garplılaşma veya Batııllık, Avrupa uygarlığının veya Batı medeniyetinin seviyesine çıkarak, Osmanlının kurtuluşunu sağlamaktır. Tanzimat döneminin medeniyetçiliği ile bir düşünce akımı olarak savunulmaya başlanmışır. İlk zamanlar Batıdan maddi uygarlık olarak adlandırılan bilim ve tekniğin alınmasıyla sınırlandırılan görüsş, zamanla Batı medeniyetinin bir bütün olarak alınması gerektiğiıni savunusuna kadar uzanmıştır. Meşrutiyet dönemine gelindiğinde birbirinden farklı görüşleri içinde brındıran bir akım haline gelmiştir. Tanzimatın medeniyetçileri gibi Osmanlı birliğini ve varlığını korumak amacıyla batılılaşmayı savunanlar, sadece eğitim ve öğretim yoluyla toplumun amacına ulaşılacağı kanaatini taşımışlardır. Emrullah Efendi ve Satı Bey bunlara örnek gösterilebilir. Batıcılar içinde Osmanlının çöküşünü sosyal kurumların eksikliğine bağlayanlara göre ise, yapılması gereken şey, Batı medeniyetini yükselten ve ileri toplumsal yapıyı ortaya çıkaran radikal bir eğitim sisteminin kabul edilmesiydi. Prens Sebahattin ile özdeşleşen bu görüşe "Mesleki İçtimai" adı da verilmiştir. "Servet-i Fünun" ve "Ulum-u İçtimaiyye" etrafında toplanan pozitivist batıcıların bir kısmı sosyalizm görüşüne kadar ilerlemiştir. Materyalizm düşüncesinden etkilenmiş olan grup ise, bütün gerçeği Batıda görüyor ve Doğuya ve geçmişe bakmayı gerekli görmüyordu. $\mathrm{Bu}$ noktada positivistlerden daha radikal batıcı olarak görülmüşlerdir. Ethem Nejad, Ahmet Rıza, Hüseyin Hilmi, bu gruba örnek gösterilebilecek isimlerdendir. Batılllaşmada en radikal olanlar ise Jön Türklerin içinden çıkan ve "kuvvetli ve üstün olan herşey Batıdadır" düşüncesini taşıyanlardır. Onlar için Batılılaşma radikal biçimde gerçekleştirilemezse, Osmanlının hayatta kalma şansı yoktur. Batılılaşmayı isteyenleri ilerici, istemeyenleri gerici olarak nitelendirmişlerdi. Genel olarak İçtihad dergisindeki yazılarıyla görüşlerini savunmuşlardır. Bu düşünceyi savunanlar arasında Abdullah Cevdet, Kılıçzade Hakkı, Celal Nuri gibi isimler gösterilebilir (Ülken, 1992:205-207).

Pozitivizmin etkisinde olan Osmanlı aydınlarından bir kısmı, din dışı düşünce akımlarıyla ilgilenmeye ve etkilenmeye başlamışlardır. Darwin'in evrim teorisi başta olmak üzere biyolojik materyalizm, fizyolojist akımlar Osmanlı'da materyalist düşüncenin kaynakları olmuşlardır. Modern eğitim kurumlarının kurulması ve özellikle de "Mekteb-i T1bbiye"nin öğretim programı ve eğitim kadrosundaki yabancı hocalar, materyalist düşüncenin gelişmesini sağlamıştır. Felsefi olarak maddeciliği ve edebiyatta ise gerçekçiliği savunan Beşir Fuat, materyalist düşüncenin öncülüğünü yapmıştır. $\mathrm{Bu}$ düşünce radikal biçimde batılılaşma düşüncesini önemli ölçüde etkilemiştir. II. Meşrutiyet döneminde biyolojik materyalizmi benimseyenler arasında Baha Tevfik, Kılıçzade Hakkı, Abdullah Cevdet gibi isimler vardır ve batılılaşma ve özellikle de din ile ilgili savunuları bu düşüncenin yoğun biçimde etkisi altındadır. (Türkiye Tarihi C.IV, 2008:401).

Batılılaşmanın her alanda yapılmasını devletin çöküşünü önleyecek tek çare olarak gören bu anlayışa en yoğun tepki islami çevrelerden gelmiştir. Bu noktada Sebilürreşad ve İçtihad dergileri çok s1k tartışmalara girmiştir. Batılılaşma düşüncesine tepki olarak ortaya çıkan İslamcılık düşüncesinin savunucuları, zaman zaman İttihat ve Terakki hükümetlerini de etkilemeyi başarmış; savundukları radikal değişiklikler nedeniyle batıcıların baskı altına alınmasını sağlamışlar.

Batıcıların batıya hayranlıkları, çağa en uygun devlet ve millet olarak Batıyı görmelerinden kaynaklanıyordu. Batı gibi olmanın tek yolu, geçtikleri yolları ve aşamaları takip etmekti. Batıcılar toplumlar arasındaki sosyal ve kültürel farklar üzerinde yeterince düşünmemiş veya önemli görmemişlerdir (Tunaya, 1996:78). 
Abdullah Cevdet, Namık Kemal'in aydınlamacı düşüncesini daha açık ve somut hale getirmiştir. Bu durum ilk bakışta tüm geleneklerin ve değerlerin yıkımı gibi görünmektedir. Hurafeler ve boş inançların cahilliği körüklediği savunularak kaldırılmasını istemiştir. Bunları toplumsal geriliğin nedenleri olarak görmüştür (Berkes, 1975:223).

Batılılaşma tarihi, yüzyıldan daha fazla bir süreye dayanmasına rağmen, II. Meşrutiyet döneminde görüş ayrılıklarını pek değiştirmemiş, hatta daha da keskinleştirmiştir denilebilir. İttihat ve Terakki hükümetleri Osmanlıcılık politikasıyla yola çıkmalarına rağmen, batılılaşmayı bir parti programı gibi görmüşlerdir. Milliyetçiliği batılılaşmak, hatta laikleşmek anlamında saymışlardır. Tanzimattan itibaren laiklik yolunda atılan adımlara hız kazandırmışlardır. Çoğu kere çok da istikrarlı olmasa da gelenekçiliğe ve hurafelere savaş açmışlardır. Bu dönemde Batının düşüncelerine ve kurumlarına kapılar tamamen açıktır. Bir çok cesur kararlar almasına rağmen, Osmanlıcı ve İslamcı kadro yapısı nedeniyle zaman zaman çekingen ve hatta muhafazakarlara ödünler vermiş, Batıcıları dergi çıkarmaktan veya yazı yazmaktan alıkoymuştur. (Tunaya,1996:48-49) Zaten iktidarı boyunca din politikasında tutarlı olduğunu söylemek zordur. Bununla birlikte daha önce tabu olarak görülen ve tartışılmasına izin verilmeyen bir çok konu - mesela dinde reform, ibadetin Türkçeleştirilmesi, Kuran'ın Türkçeye çevrilmesi, Arap harfleri yerine Latin harflerinin alınması gibi- ilk defa bu dönemde kamuoyu gündemine sokulmuş ve tartışmaya açılmıştır. Bu tartışmalarla dinle ilgili bir çok konu tabu olmaktan çıkarılmış; aydınların ve bir kısım halkın bilgilendirilmesiyle cumhuriyet dönemi laiklik politikasının toplumsal kabulüde etkili olmuştur.

II. Meşrutiyet döneminin en tanınmış ve kalemi en keskin olan, en çok eleştirilen yazarlarından biri Kılıçzade Hakkı'dır. Biyolojik materyalizmin ve Ömer Hayyam'ın düşüncelerinden önemli ölçüde etkilenmiştir. Yazılarının büyük bir kısmı dinin toplumlar üzerindeki etkileri, dinin devlet işlerinden ayrılması, İslam dininin Arap kültürünün etkisinden kurtarılması, siyer yazıcılığı ile ilgilidir. Özellikle dini özünden çıkarıp ondan çıkar sağlayan, halkı hurafelerle cahilleştirdiğini düşündüğü sahte softalar ve dervişlere savaş açmıştır. Yazıları büyük ses getirmiş; ancak İslamcı cephe ve ilmiye sınıfına mensup gruptan çok eleştiri almıştır. Hatta bu çevrelerin yaptığı baskılar, O'nun hayatında önemli değişikliklere neden olmuştur.

Cumhuriyetin ilanından sonra gerçekleşecek bir çok devrimden ilk kez bahsetmesi nedeniyle ilgi çekmiştir. Bir kahin değildi tabi ki, ancak, hayalindeki Türkiye, kısmi olarak yeni Türkiye’nin kurucusu Mustafa Kemal'in hayaliyle örtüşmüştü. Hatta Batının kültür ve uygarlığının yanı sıra gelişmişliğinin altında yatan düşünsel birikimin de alınmasını savunduğundan dolayı-özellikle din konusundaki görüşleri- onun "Batılılaşmış bir doğulu" olarak nitelendirilmesine neden olmuştur. (Altıntaş, 2008:93-94).

O’nun özellikle din konusundaki görüşleri, yeterince irdelenmeden din karşıtlığının bir yansıması olarak değerlendirilmiştir. Özellikle radikal Batıcı olarak isimlendirilmeleriyle birlikte görüşleri çoğu kere olumsuzlanmaktadır. İçtihad yazarı ve batıcı olarak Abdullah Cevdet'in de gölgesinde kaldığı söylenebilir. Bu noktada Kılıçzade Hakkı'nın din ve laiklikle ilgili görüşlerini meşrutiyet ve cumhuriyet dönemlerini ayrı ayrı ele alarak, din ve laiklik konusundaki görüşlerini ve ve dönemsel farklılıklarını irdelemeye çalışacağız. Tabiki onun görüşlerinin yeni Türkiye'nin laiklik ilkesi ve uygulamasıyla benzerlik ve farklılıklarını, sürece etkilerini ortaya koymaya çalışacağız.

\section{Kılıçzade Hakkı'nın Yaşam Öyküsü}

Ass1 adı İsmail Hakkı olan Kılıçzade, 1872 yılında Niş’de doğmuştur. Ailesiyle birlikte, 187778 Osmanlı-Rus Savaşı nedeniyle Manastır'a kaçmıştır. Kısa bir süre sonra babasının ölmesi üzerine "babasız, yurdsuz ve servetsiz bir muhacir çocuğu" olarak okuma yazma bilmeyen annesiyle yaşamaya başlamıştır. İbtidai, askeri rüştiye ve idadi eğitimini burada tamamlamıştır. Kendisini "zihni evvel" ve haşarı olarak tarif eden Kıliçzade, ilk olarak mahalle mektebine gönderilmiştir. Burada bir süre okuduktan sonra önce askeri rüştiyeyi, arkasından askeri idadiyi başarıyla tamamlamıştır (Hür 
Fikir, 20 Teşrini-Evvel 1926:3;Türk Parlamento Tarihi, 1996:404). 1890'da Mühendishane-i Berri Hümayun'da eğitime başladı. 1880'lerden sonra Osmanlı kültür yaşamına giren materyalizmden etkilendi. Özellikle biyolojik materyalizm düşüncesi daha sonraki yıllarda din konusunda yazacağı pek yazıya kaynaklık etmiştir. Ömer Hayyam'ın şiirlerini okumaya okul yıllarında başlamış ve oldukça etkilenmiştir. Bir yandan positiviz, darvinizm, biyolojik materyalizm gibi Avrupa merkezli düşüncelerden etkilenerek kendi düşünce sistemini oluşturmuştur. Diğer yandan ülke içinden de Ömer Hayyam'ın akılcı anlayışından etkilenmiştir (Pekdoğan, 2002:415).

1894 'te Mühendishane-i Berri Hümayun'dan topçu üsteğmen olarak mezun olmuştur. 1889'da Selanik'teki kolorduya katıldıktan bir süre sonra, 1903'te II. Abdülhamit'in baskıc1 rejimine son vermek ve meşrutiyeti ilan ettirmek amacıyla kurulmuş olan İttihat ve Terakki Cemiyeti'ne katılmışır (Kutay, 1997;303). Manastır, Bağdat, Yemen, Edirne ve İstanbul kolordularında görev yapmıştır. Bağdat Askeri İdadisi’nde kitabet Muallimliği görevini de bir süre yürütmüştür. Anadolu ve Rumeli'de bir çok yerde görev yapmıştır. Meşrutiyetin ilanından sonra Mustafa Kemal ile Selanik'te tanışmış; 1911'de Mustafa Kemal'in Erkan-1 Harbiyye seyahatine katılmış ve O'nun yönettiği harp oyunlarında bulunmuştur(Türk Parlamento Tarihi, 1996:404). Ayn1 yıl Sütlüce Malumat Ambarı Müdürlüğü'ne atanmıştır. 1912'de ise, İstanbul Efrad Divanı-Harp Başkanlığı'na, ardından muhafızlık maiyetindeki divanı harp üyeliğine getirilmiştir. Son görevi sonrasında rütbesi binbaşıllğa yükseltilmiştir (Pekdoğan, 2002:415-416;Türk Parlamento Tarihi, 1996:404).

Kılıçzade'nin hayatında 1912 yılı çok önemli bir yere sahiptir. İstanbul'da görev yaptığı sırada yazdığı, "Pek Uyanık Bir Uyku" başlıklı yazıyı bizzat İçtihad Dergisi’ne giderek, daha önce tanımadığı Abdullah Cevdet'e verilmek üzere yazı işlerine teslim etmiştir. Arzu ettiği ve görmek istediği Türkiye'yi tarif ettiği bu yazı İçtihad Dergisi'nin 55.sayısından başlayarak birkaç sayıda yayınlanmıştır (İçtihad, 21 Şubat 1328:1226-1228;7 Mart 1329;1261-1264). Bu yazı çok dikkat çekmiş ve büyük ilgi görmüştür. Bu ilk yazıya yönelik ilginin daha dumanı tüterken, Balkan Savaşları'ndaki yenilginin nedenlerini anlattığ "Nasıl Mağlup Olduk" başlıklı yazı dizisini iki bölüm halinde yayınlamıştır (İçtihad, 28 Şubat 1328:1242-1246; 7Mart 1329:1265-1267; 14 Mart 1329:12831285; 21Mart 1329:1290-1293). Yayın hayatında en çok ses getiren yazısı ise, ilk kez 58. sayıda yer alan yazı dizisi olan "Sahte Softalığa ve Dervişliğe İlân-1 Harp" ismiyle yayınlanan makalesidir (İçtihad, 14 Mart 1329:1277-1281). Bu yazı nedeniyle dergiye büyük talep olmuş ve dergi bir haftada tam 3 kez basılmıştı. İçtihad Dergisi çalışanları ilk yazısından hemen sonra keskin ve korkusuz kaleminden dolayı"Kılıçzade" lakabını vermişlerdir (İçtihad, 10 Şubat 1923; 3132-3133).

Bir yandan İçtihad'taki yazılarına devam eden Kılıçzade Hakkı, bu arada ilk basılı eserini yayınlamıştır. Çoğunlukla bu dergide yazdığı yazıları içeren ve 1913 yılında basılan "İ'tikâdât-1 Bâtılaya I'lânı Harb" isimli eserin, dini aşağıladığı, din inkılabı yapmaya çalıştığı ileri sürülerek, hakkında dava açılmış, ancak sonuç çıkmamıştır.

Mesleği askerlik olan Kılıçzade'nin yazıları, İttihat ve Terakki hükümetinin pek hoşuna gitmemiş olacak ki, daha önce herhangi bir uyarı yapılmadan 15 Ocak 1914'te emekli edilmiştir. Kendisine neden emekli edildiği konusunda bir yanıt verilmediğini belirten Kılıçzade Hakkı, bu olaydan "Enver Şah" diye isimlendirdiği Enver Paşa'nın sorumlu olduğu kanaatindedir. Softalara savaş açması, hanedan aleyhinde yazı yazdığı için hanedanın "bendesi" ve "bir sultan hanımın kocası" olduğu için onu cezalandırdığını ileri sürmektedir (Hür Fikir, 25 Nisan 1927:2). Enver Paşa'nın "sahte bir dindar" olduğunu, İttihat ve Terakki Fırkası'nın II. Abdülhamid vari bir İslam politikası hevesine düştüğünü ileri sürmüştür. O'na göre yazıları İttihatçıların politikasına zararlı görüldügü için hiçbir neden gösterilmeden emekli edilip ordunun dışına itildiğini ileri sürmüştür (Hür Fikir, 24 Mart 1926:2)

Her ne kadar emekli edilmesinin kendisini özgür kıldığını belirtse de çok içerlediği ve İttihatçılara kinlenmesine neden olduğu anlaşılmaktadır. Cumhuriyet döneminde İttihatçılarla ilgili yazdığı her yazıda, dinmek bilmeyen kin ve öfkesi hissedilmektedir. Anılarını anlattığı yazı dizisinde, sivil hayata alışmanın O'nun için ne kadar zor olduğu görülmektedir. 
Emekliye sevkedilmesinin hemen arkasından Celal Nuri Bey ile İçtihad'a rakip olarak 16 Şubat 1914'te "Hürriyet-i Fikriyye" dergisini çıkarmağa başlamış; bu arada İçtihad'daki yazılarına ara vermiştir. Hürriyet-i Fikriyye'deki yazılarında kadın, din, evlilik ve askerlik alanlarında çağdaş anlayışın ve uygulamaların alınması gerektiğini savunmaktaydı. Tesettürün kaldırılması, Cuma hutbelerinin Türkçe okunmasını savunan yazılar ve Latin harfli makalelerin basılması nedeniyle dergi birkaç kez kesintiye uğramışırı. Bu arada dönemin Dahiliye Nazırı Talat Paşa, kendisini çağırmış ve Latin harfleri konusunda uyarılmıştır. Yayın politikasında değişikliğe gidilmediği için dergi Mayıs 1914'te kapatılmıştır (Pekdoğan, 2002.425). Bunun üzerine "Serbest-i Fikriyye" adıyla bir dergiyi aynı ayda çıkarmaya başlamışlardır. Bu dergi de diğeriyle aynı akibete uğramış ve bir ay içinde kapanmıştır. 1914 Haziran ayından önce Uhuvvet-i Fikriyye dergisi çıkarılmıştır. Ancak İttihatçı hükümet Kılıçzade Hakkı'ya yazı yazdırmamakta kararlıydı. Kısa zaman sonra bu dergiyi tamamen kapatma kararı vermişti.

$\mathrm{Bu}$ arada Sebilürreşad'ın Hamdi Hocası'nın sert eleştirilerine maruz kalan Kılıçzade, hükümeti devirmeye teşebbüsle suçlanmış ve Abdullah Cevdet ile brlikte tutuklanarak Bekirağa bölügüne hapsedilmiştir. Günlerce sorgulanmış, arkasından Merkez Kumandanı Halil Paşa'nın desteğiyle serbest bırakıldı, bir ay sonra da harb divanında beraat etmişti. Ancak bu olaydan sonra İstanbul'da kalmasının kendisi için tehlikeli olacağı düşüncesiyle bir an evvel taşraya, bir memuriyete tayin olup gitmek istemişti. Nitekim sonunda Çanakkale Muhacirun Katibliği görevine atandı. 29 Mayıs 1330/12 Haziran 1914'te Çanakkale'ye gitmek için yola çıkmıştır (Hür Fikir, 25 Nisan 1927:2).

Hükümetin her çıkardığı dergiyi kapatmasındaki kararlılık karşında bir süre yazı yazmayan Kılıçzade, Çanakkale'de sadece muhacirun heyetinde çalışmamış aynı zamanda Çanakkale Muallim Mektebi'nde Müdürlük ve Riyaziye öğretmenliği de yapmıştır. 1917'de İzmit Muhacirun Müdürlüğü'ne tayin edilmiştir. Milli Mücadele yıllarını İzmit’te geçiren Kılıçzade Hakkı, halkın mücadeleye destek vermesi ve örgütlenmesi için çaba harcamıştır. İzmit’te, Orta Mektebde fahri olarak Tarih, Coğrafya, Türkçe, Malumatı Medeniye derslerine girmiştir. Hükümetin tutumu nedeniyle 1914-18 yılları arası dönemde yazı yazmamıştır (Pekdoğan, 2002:416). Sadece 1332/1916 yılında I'tikadat-1 Batılaya İ'lan-1 Harb'in neredeyse ilk baskısı ile aynı olan ikinci baskısını yaptırmıştır.

Yazım hayatına Kocaeli Vilayet Gazetesi çıkararak dönmüştür. Milli Mücadele lehine yazılar yazmıştır. 1919 seçimlerinde İzmit'ten milletvekili olmak için aday olmuş, ancak seçilememiştir. İzmit seçimlerine 30 kadar aday katılmıştır. Bunların içinde mebus seçimlerine bir programla katılan tek aday Kılıçzade Hakkı'dır. İzmit Muhacirun Umum Müdürü Kılıçzade Hakkı, seçim programının girişinde milletvekili olmak istemesinin nedeni milli egemenliğin gerçekleştirmek olduğunu göstermiştir (Çavdar, 1981:21-23).

1919 seçimleri sırasında Kılıçzade Hakkı, Kocaeli Gazetesi’ne milletvekili adaylarının taşıması gereken niteliklerini belirterek, bu nitelikleri taşımayanlara oy verilmemesini istemiştir. Gazete haberinde mebus seçimlerinde en esaslı programın Kılıçzade Hakkı'ye ait olduğu ileri sürülmektedir. Kızların serbestçe gideceği ve modern okulların köylere kadar yaygınlaştırılması, imamların köylüleri uyandıracak nitelikte önder gibi yetiştirilmesi, din işlerinin hükümetten ayrı tutulması, Şeyhü'l-islamın kabine dışı bırakılması, ekonominin geliştirilmesi konular, seçim programında yer almıştır (Çavdar, 1981:27-33). Teokratik yapıya sahip Osmanlı için özellikle din konusundaki vaatleri, savunduğu düşüncelerini bu dönem için radikal sayılabilir.

Milli Mücadele'de kayıtsız şartsız emrinde olduğunu Mustafa Kemal'e bildiren Kılıçzade (Hür Fikir, 19 Ocak 1929:2), kendisine milli kuvvetlerle çalışma talimatı verildiğini belirtmiştir. Mustafa Kemal'in 16 Haziran 1922'de İzmit'e gelişi sırasında Kocaeli gazetesini kendisinin hazırladığını ifade etmiştir. İzmit'e bu ilk gelişi sırasında kendisi ile görüşmüş ve sohbet etmişlerdir (Hür Fikir,23 Ocak 1930:2). 
Mustafa Kemal'in 16/17 Ocak 1923 tarihinde İstanbul gazetecileriyle düzenlediği basın toplantısına İleri Gazetesi'ni temsilen katılmıştı. Milli Mücadele döneminde İleri Gazetesi'nin İzmit temsilcisi olarak çalışmış olan Kılıçzade'nin basın toplantısında sorduğu sorular, bir hayli dikkat çekicidir. Mustafa Kemal'e yeni devletin dininin olup olmayacağı, dine bağlı kalıp kalmayacağını sormuştur. Mustafa Kemal de "evet, İslam dini” olduğunu belirtmiştir. Devlette dinin etkin olup olmayacağı konusundaki soruya ise ülkede özgürlük olduğunu 1srarla vurgulayarak, kesin bir cevap vermekten kaçınmıştır (Mustafa Kemal, 1993:137-138).

Şubat 1923 'te İçtihad Dergisi'nde yeniden yazmaya başlamıştır. Bu süreçte gazete Kılıçzade Hakkı'nın yeniden yazmaya başladığını okurlarına bildirirken, O’nun geçmişteki yazılarından bahsetmiştir. Kılıçzade'den gelen mektup da İçtihad Dergisi'nin sayfalarında yer bulmuştur. Bu mektupta eski düşüncelerinde değişme olmadığını, ve on yıl önceki heyecana aynen sahip olduğunu vurgulamıştır. Türkiye'de fikir hürriyetini tam olarak egemen kılana kadar ölmeyeceğinin ve mücadeleye devam edeceğinin altını çizmiştir (İçtihad, 10 Şubat 1923:3133-34).

Cumhuriyetin ilanı onda büyük heyecan yaratmıştır. Cumhuriyetin ilanından sonra Mustafa Kemal'in yönlendirmesiyle İzmit'te Hür Fikir Gazetesi'ni çıkarmaya başlamıştır. Ocak 1924 tarihinde yayına başlayan bu gazete, 1931 yılına kadar sadece yerel değil, ulusal basını ve kamuoyunu etkileme gücüne sahip olan ender yerel gazetelerden biri olmuştur. Özellikle devletin din ve laiklik konusundaki politikalar başta olmak üzere, tüm ilke ve devrimlerin yılmaz savunucularından biri olmuştur. Zira Atatürk döneminde yapılan devrimlerden bir kısmı, O’nun 1913'te İçtihad Dergisi'ne ilk kez yazdığı ve bir rüyasını anlattığı yazısında belirtilmişti. O gün için ütopya denilebilecek bu devrimleri, Osmanlı Devleti'nin ayakta kalması için öngörmüştü.

Genel olarak yazıları din başta olmak üzere, sosyal yaşam, eğitim, alfabe değişimi, kadın, ekonomi, dış ilişkiler, siyasi gelişmeler gibi hemen hemen sosyal ve kamu hayatının her alanını kapsıyordu. Bununla tahmin edileceği gibi çoğunlukla din ve sosyal yaşamda dini etkileyen unsurlar, dinler tarihi, peyganberlerin hayatları gibi konularında yazılar yazmıştır. Biyolojik materyalizmin ve pozitivizmin etkisi altında yazılarını kaleme almış ve halkı etkilemeye çalışmışır. Din yerine bilimin temel alınması gerektiğini, dinin vicdan meselesi olduğunu savunmuştur. Alfabe değişikliğini en çok savunan kişilerin başında gelmektedir. Sik sık dini çevrelerin özellikle de yılmaz muhalifleri olan Sebilürreşad yazarlarının eleştirisine uğramıştır. Zaman zaman din adamları tarafından haklarında dini aşağılama iddiasıyla açılan davalar beraatle sonuçlanmıştır.

Kılıçzade, 1927 yılında Kocaeli kentinin milletvekili olarak, ilk defa Meclise girmiştir. 1931 y1lından 1946'ya kadar dört dönem Muş milletvekili olarak Meclis'te görev yapmıştır. 1945'ten sonra da astronomi ve tarihle ilgili yazılar kaleme almıştır. Hayatı boyunca Batıcı-Türkçü çizgisinden asla sapmamıştır. 1960 yılında yaşamını yitirmiştir.

\section{Dinler Hakkındaki Görüş̧leri}

Kılıçzade Hakkı, yazın yaşamına başladığı 1912 yılından itibaren, yazdığı kitap, makale, gazete ve dergi yazılarında çoğunlukla din konusunu ele alarak, genelde dinlerin kökenleri, peygamberler, toplumlar üzerindeki etkilerini eleştirmiştir. Özelde ise; İslam olarak topluma sunulan kural ve ibadetleri, dini kuralların yönetime etkin olmasını, dinin siyaset aracı olarak kullanılmasını eleştiri konusu ederek, sahte derviş ve softalara karşı mücadele etmeyi ilke edinmiştir.

Kılıçzade Hakkı'nın dinlere bakışını etkileyen temel düşünceler positivizm, biyolojik materyalizm ve Darvinizmdir. Bunun yanı sıra Osmanlı Devleti'nin içinde bulunduğu çöküş süreci de devletin ve toplumun temelini oluşturan din düşüncesini sorgulamasına neden olmuştur.

Yazın yaşamının ilk yazısında, o dönem için ütopik nitelikte olan, devlet ve toplum yaşamında ve din alanında bazı değişimleri öngörmüştü. Bu yazıyı 1913'te yayınladığı "İtikadat-1 Batılaya İlanı Harp” başlığını taşıyan ve makalelerden oluşan eserinde inancının özetini vermiştir. Allah'ın varlığına 
ve birliğine, bütün kuvvetin sahibi olduğuna, koyduğu değişmez kanunlarla maddi ve manevi, batını ve zahiri dünyaları idare ettiğine inanmaktadır. İnsanlara akıl verdiğini ve serbest bıraktığını belirterek, insanların "irşad" için kendi içlerinden peygamberler ve dahiler yarattıklarını ileri sürmüştür. Allahın senet ve kanunlarıyla insanları doğru yola götürdüklerini savunmuştur (Kılıçzade Hakk1,1913:9).

Kılıçzade Hakkı, insanlığın başlangıcını neye dayandığını ve nasıl ortaya çıktığını sorgulayarak din ile ilgili görüşlerine açıklık kazandırmıştır. Allahın bir isteğiyle insanın yaratıldığını savunan dini inanışla, maddenin ezeli ve ebedi ilkesi temelinde insanlığın ortaya çıkışını açıklayan bilimsel anlayışı karşılaştırarak, ikisinin de cevaplarını tatmin edici bulmadığını belirtmiştir. O her iki tarafı, niteliğini kesin olarak bilmedikleri bir kuvvetle iddialarını açıklamaya çalıştıklarından bu kavganın kolay kolay sonlanmayacağı görüşündedir. Her iki tarafın bahsettiği kuvvetin yüzyıllar boyu sır olarak kaldığını ve insanlarda boşluk oluşturduğunu savunmuştur. "Meçhul-ü mutlak" olarak adlandırdığ 1 bu güce, ister "vacibü'l-vücud", isterse "madde ve ruh" denilsin, farketmeyeceğini ifade etmiştir. Ama sonunda Musa'nın kitabında ve Kur'an Kerim'de mucize biçimde tarif edilen Allah'1 kabul etmenin en doğru yol olacağını belirtmiştir (Kılıçzade Hakkı,1331:6-7).

$\mathrm{Bu}$ fikre rağmen, hak dinlerin ortak olarak kabul ettiği yaradılış düşüncesine inandığ söylenemez. İnsanlığın gelişim sürecini maddeci bir anlayışla açıklama gayreti içindedir. İnsanlığın yaradılma sürecinin binlerce yıllık bir tekamülün neticesinde ve takip edilebilir dönemler sonrasında ortaya çıktığı için, bilimsel maddece düşünceyi kabul edilebilir görmektedir. Onun bir nazariye değil gerçeğin kendisi olduğu kanaatini vurgulamıştır. Ortada bu kadar kanıt varken ve her an doğrulanması mümkün iken "Hazreti Allah kainatı bir lahza da yarattı" şeklindeki açıklamaların açıkça bir küfür olduğunu ileri sürmüştür. Buna dikkat etmeyen Müslümanların cezalarını çekmekte olduklarını vurgulamaktadır. Kılıçzade, Allahın insanı önce eliyle çamurdan, insanın şeklini yarattığını ve arkasından ona ruhundan nefes vererek yaradılışını tamamladığı şeklindeki hak dinlerin genel kabul ettiği düşüncesini de reddetmektedir. O'na göre; dünyanın başlangıcı ve nuru olarak nitelendirdiği kuvvetin, bağlı olduğu arzın dahil olduğu maddelerden oluşmak üzere milyonlarca yılın tekamülü neticesinde ortaya çıkmıştır. Zamanla kafası ve dimağ 1 gelişmiş ve geliştikçe ve üredikçe yavaş yavaş bedeni de değişmiştir (Kılıçzade Hakkı,1331:8-10).

Kılıçzade Hakkı'nın bu görüşleri, Darvinist ve positivist bir yaklaşımın sonucudur. Evrim kuramını din anlayışına uyarlayarak, insanın tekamül yasaları uyarınca doğal akış içinde gelişme gösterdiğini savunmaktadır. Bu noktada positivizmin kurucusu August Comte'un üç hal yasasını dine uygulamıştır. Kılıçzadeye göre, insanlar idrakleri geliştikçe, dinlerinde de bir tekamül söz konusu olmuş; "animizmi fetişizm onu da putperesti takip etmiştir ve nihayet-bidayette pek basit olmak şartiyle- asla görünmeyen bir Allaha vahide-i iman etmek dini zuhur etmiştir. Ve bu dini de peygamberler ... ihdas etmişlerdir" (Kılıçzade Hakkı,1331:13-14).

Kılıçzade Hakkı, dini oluşturduklarını ileri sürdüğü peygamberler için de en çok takdir ettiği Hz. Muhammed'dir. Halkını en iyi tanıyan O'dur. Halkı, Muhammed'in mükemmel tanıdığı kadar geçmiş peygamberlerden hiç kimsenin tanımadığını savunmuştur. Geçmiş peygamber içinde kitabı tahrif edilmeyen tek peygamberin de o olduğunu ifade etmiştir. Bununla beraber her peygamberin ümmetlerinin yeteneklerine, anlayışlarına ve çevrelerine göre etkiler yarattığını savunmuştur. Peygamberlerin her birinin ayrı nedenler için varolduklarını ve onların insanların saadeti için çalıştıklarını belirterek, onların içinde beşeriyet için "cansiperane ve fedakârca" çalışanın Hazreti Peygamber olduğunu savunmuştur (Kılıçzade Hakkı,1331:14-16).

Kılıçzade Hakkı, dört kitaplı dinin inancına aykırı olarak, dinleri ve peygamberleri, semavi veya ilahi kaynaklı görmemekte, onların dünyevi yani insan ürünü olduğuna inanmaktadır. Peygamberleri zamanın akıl ve bilimini kavrayan, diğer insanlardan oldukça üstün vasıflara sahip, yaşadığı toplumun ve halkın ihtiyaçlarını iyi bilen, üstün vasıflı bir "deha" olarak nitelendirmiştir. Bununla birlikte Hz. Muhammed'i tüm peygamberlerden en üstün ve beşeriyet için en çok çalışan 
olarak nitelendirmiştir. İslamiyeti de akla en uygun din olarak belirtmesine rağmen, temel kanunları korumak kaydıyla bazı değişikliklerin yapılmasının gerekliliğine de dikkati çekmiştir.

Din konusundaki yukarıda belirttiğimiz görüşler, II. Meşrutiyet dönemi için radikal kabul edilmekle birlikte, yine de görüşlerini tam olarak açıklayamadığını, halkın tepkilerinden çekindiğini belirtmiştir (Kılıçzade Hakkı, 28 Haziran 1329:70). Bu nedenle cumhuriyetin ilanından sonra görüşlerini giderek daha açık ve dini daha sert biçimde eleştirerek yazmıştır.

1914 yılından itibaren din konusunda yazılarına ara veren Kılıçzade Hakkı, Cumhuriyetin ilanından hemen sonra kaldığı yerden yazmaya devam etmiştir. Meşrutiyet döneminde tam olarak açıklayamadığ görüşlerini, yeni dönemde bulduğu fikir özgürlüğü ortamında istediği gibi açıklama gayretine girişmiştir. 1924 yılı başlarında çıkardığı Hür Fikir Gazetesi’ndeki yazılarında Ludwing Büchner ve Felix İsnard gibi düşünürlerin etkisiyle dinin yerini, biyolojik materyalizmin almas1 konusundaki görüşlerini açılamaya çalışmıştır. O’na göre, bilimin ve fennin herşeyi açıkladığını, yaratılmış canlıları insan şeklinde doğa üstü güçleri olanlar değil, ezeli ve ebedi olan tabii kanunlar tarafından yönetildiği, doğa üstü yeteneklere sahip insanlar olmadı̆̆ı, semavi dünyanın olmadığının bilim tarafından kanıtlandığını savunmuştur (Pekdoğan,1999:224-225). Dinin de akıl ve bilimle ilgisi olmadığından ve yararının da bulunmadığından bahsetmektedir.

Kılıçzade, Cumhuriyet döneminde dine yönelik en sert yazılarını milletvekili olduktan ve laiklik ilkesinin benimsenmesinden sonra yazmıştır. "Devletin dininin, din-i İslamdır" maddesinin çıkarılmasının ikinci yıldönümünde Hür Fikir Gazetesi'nde "Muhammed" başlıklı bir yazı dizisi yayınlamaya başlamıştır. Bu dizinin ilk sayısında din konusundaki görüşlerini en açık biçimde yazmıştır. Peygamber Muhammed'i, "Arap münci, medeniyetçi ve teşkilatçısı Büyük 'Muhammet Mustafa" olarak nitelendirmiştir. Mustafa Kemal'i onun yoldaşı ve adaşı olarak nitelendirmesinin yanı sıra, aynı vasıfları sadece başına Türk kelimesini koyarak, onun için de yazmıştır (Kılıçzade Hakk1, Hür Fikir,10 Nisan 1930:2).

Kılıçzade Hakkı bu yazı dizisinin başında din konusunda şunları yazmıştır:

"Dinler; ruhî, siyasî, içtimaî ve bilhassa iktisadi ihtiyaçların ifadesi olmaktan başka bir şey değildirler; ve hepsi de birer felsefe ve nazariyat sistemleridir; çünkü tecrübe ve müşahadeye istinat etmezler; bilakis zan ile ifade edilen akideden doğan imana ve ya imandan doğan akidelere istinat ederler; göklerden geldiği iddia olunan kanunların bir mecmuasıdır. $\mathrm{Bu}$ kanunları layetegayer, değişmez oldukları için cemiyet hayatı için çok tehlikelidirler. Bunların çemberinden kurtulmak için onu parçalamak lazım gelmiştir. Çünkü aslında basit olan bu akait teşkilatı, şunun bunun eline geçtikten sonra içinden çıkılmaz olmuştur.

"Halbuki kâinatta hûkûmran olan tabiatın değişmez ve değiştirilemez umumî kanunlarıdır: Mikaniki ve fiziki... Tabiat kanunları haricinde hiçbir şey bulunmadığı için Harika-Mucize ler yoktur: harikalar vehim mahsulü ve yahut siyasi düşüncelerin icat eserleridir".

Kılıçzade Hakkı bu görüşleriyle biyolojik materyalizm anlayışından hareketle dinleri, ortaya çıkış sürecinin nedenlerini ve sonuçlarını, amaçlarını açıklama gayreti içindedir. Dinin toplumlar için zararlı olduğu görüşünü belki ilk kez bu kadar açı ortaya koymaktadır. Peygamberleri de kendi dönemlerinin çürümüşlüğünden ve geri kalmışlığından toplumu çıkarmak ve doğru yola sevk etmek amacıyla ortaya çıkan toplumun dehaları olarak vasıflandırmıştır. Bu durumda dinlerin kurallarının günümüzde geçerli olamayacağı konusundaki görüşlerini bu açıklamalarıyla kanıtlama çabasındadır. Dini ilahi olmaktan çıkararak, onu döneme ve ihtiyaca göre her zaman değiştirlebilir, bir kurallar bütünü olarak görmektedir.

Kılıçzade Hakkı'ya göre, tabiat güçlerini bilmeyen ilk insanlar, bunlardan korkmuşlar ve her birine ayrı isimler vererek onları ilahlaştırmışlardır. İnsanların korkularından yararlanarak veya onları korkutarak yüzyıllar boyunca din adı altında onları yönetmişler ve istediklerini yaptırmışlardır. Yeni 
dinlerin halinden memnun olmayan ve fakir sayılan topluluklarda ortaya çıktığını, mücadeleyi kazandığı zaman zengin kitlenin eline geçerek, bir bask1 aracına dönüştügünü ileri sürmüştür. $\mathrm{Bu}$ noktada gerçek davanın egemenlik ve "mide davası" olduğu anaatindedir; hayatta kalmak ve daha iyi yaşama endişesinden kaynaklanan sonsuz bir mücadele olması nedeniyle de dini bir çıkar aracı olarak görmüştür (Kılıçzade Hakk1, Hür Fikir, 17 Nisan 1930:2).

İnsanların toplumsal hayatta giderek daha iyisini yeme, içme ve yaşama amacında olduğu için mücadele ettiği kanaatindedir. İnsanlara bu zevki Allah'ın vermesine rağmen, bu zevk isteğini tatmin etmek için insanoğlunun sınırsız zalimane tutumu karşısında, aileler ve toplumlar büyük zararlar görmektedirler. İnsanların büyük acılar yaşadığı ve feryatlar ettiği bu olaylar karşısında, dinlerin ve dindarların Allah'ın neden hareketsiz kaldığını sorgulamaktadır. Yaşananların hesabının ahirette görüleceği konusunda dindarların verebileceği cevabı da tepkiyle karşılayarak, bunun olacağına dair kanıt veya senet olup olmadığını alaycı biçimde dile getirmiştir (Kılıçzade Hakkı, Hür Fikir, 24 Nisan 1930:2).

Allah'ın dünyadaki tüm afetlere, savaşlara, felaketlere, salgın hastalıklara müdahale etmeyip kayıtsız kalmasını eleştirmesi ise O'nun inacını açık biçimde ortaya koyar niteliktedir. O, peygemberlerin tarif ettiği gibi bir Allah olsaydı, fenalıkların oluşmasına engel olacağını savunmaktadır. Eğer olumsuzluklarla ilgilenmiyor ve kayıtsız kalıyorsa onun nazarında iyi, kötü, güzel, çirkin, hayır ve şer olmadığını ileri sürmüştür. Peygamberlerin bahsettiği gibi bir Allah varsa, bu denli büyük kötülüklere ve felaketlere kayıtsız kalmasının mümkün olmayacağını ifade etmiştir (Kılıçzade Hakk1, Hür Fikir,10 Nisan 1930:2).

Bu görüşlerine karşılık daha 1925 'teki yazılarında dinin gerekli olduğunu ve varlığını tasvip ettiğini belirtmekteydi. Ancak bu dinin basit olmasını ve o sert ve acımasız hayatta herkesin taptığı her çeşit ihtiyaçların tatmine hevesli olmamasını istiyordu. Daha çok vicdanlara hitap etmesinden ve moral vermesinden yanaydı (Hür Fikir, 16 Mart 1925, 60:1)

Kılıçzadenin bu görüşlerine yakından bakıldığında, II. Meşrutiyet dönemine oranla din konusundaki görüşlerini daha kesin ifadelerle kaleme almıştır. Dinin ilahi olmadığını, peygamberlerin belirttiği Allah'ın varolduğunun kanıtlanamayacağını savunmuştur. O'nun bu düşünceleri oldukça keskindir ve toplum nazarında da oldukça cüretkârdır. Bunun yanı sıra dinin temellerini, ortaya çıkış nedenlerini ve dindar kitleleri aktarırken, çoğunlukla olumsuz bir bakış açısına sahip olduğu hemen görülecektir. Özellikle laikliliğin kabul edilmesinden sonra görüşlerini çok açık biçimde yazmaya başlamıştır. Laik bir devlette dini görüssler konusunda sınırlama konulamayacağı konusundaki görüşleri cumhuriyet döneminde O'nu haklı çıkarmıştır. Hakkında başta Kocaeli müftüsü olmak üzere din adamları ve İslamcı yazarlar tarafindan onlarca dava açılmasına rağmen herhangi bir mahkumiyet söz konusu olmamıştır.

\section{İslam Dini ve Dinde Reform Düşüncesi}

Kılıçzade Hakkı, kendini bildiğinden beri dinlerin herşeye karışmasına veya en adilerine varıncaya kadar yapılan her işin dindarlığın veya dinsizliğin göstergesi sayılmasına çok kızdığını yazmıştır. Din konusundaki hassasiyetinin kaynağını belirtmemesine rağmen, dini uygulamalara yönelik olan eleştirel tutumunun okul yıllarından itibaren varlığı bilinmektedir. Bu tutumu özellikle gazete ve dergilerde yazı yazmaya başladıktan sonra, dine/İslam dininin uygulamalarına sert eleştirilere, dinin etkisini kırmaya yönelik çabalara dönüşmüştür (Hür Fikir, 11 Mayıs 1925:1).

Kılıçzade Hakkı "Muhammet" adlı yazı dizisine başlarken, kitap haline getireceği bu yazıların, "şu güne kadar Müslümanlar diyarında yazılmamış bir şekilde yazılacağı için, okuyanlardan belki bir çoklarının ruhlarını incitecek ve sarsacaktır" demiştir. Amacının yıkmak olmadığı belirterek, bu konudaki fikirlerini ilk defa yazmadığını ve bu nedenle okuyucuların çok da şaşırmayacakları kanaatindedir. Kendisinin olduğu gibi görünmekten ve düşüncelerini açıklıkla yazmaktan asla 
kaçmadığını ve kaçmayacağını ifade etmiştir. İnancını “...insan ve Türk olmak!” olarak belirtmiştir (Kılıçzade Hakk1,Hür Fikir, 10 Nisan 1930:2).

"Pek Uyanık Bir Uyku" başlığı taşıyan yazısında, nasıl bir ülke hayal ettiğini ortaya koymuştur. Hayal ettiği bu yeni ülkede, dinin devlet ve toplum hayatındaki rolü oldukça kısıtlanmış ve neredeyse bireylerin vicdanlarına indirgenmişti. Bu makalede, tekke ve zaviyelerin kapatılması, evliyaya adaklar adanması ve muska ve üfürükçülüğün yasaklanması, sarık sarma ve cübbe giyme hakkının sadece yüksek din adamlarına tanınması, medreselerin kapatılması, hutbelerin günün ihtiyaçlarına göre düzenlenip Türkçe okunması, içtihad kapısının yeniden açılması, Kuran'ın Türkçeye çevrilmesi, çeşitli mezheplerin bir araya gelmesi ve içtihadla tek bir mezhebin oluşturulması, kadının din baskısı altından kurtarılarak kıyafette ve toplum yaşamında özgür hale getirilmesi ve Arap harfleri yerine Latin harflerinin esas alınması öngörmüştür. (Kılıçzade Hakkı, İçtihad, 21 Şubat 1328:12261229). Sadece din alanındaki değişimleri bile düşündüğümüzde, o döneme göre ne denli kökten değişiklikleri savunduğu görülecektir. Yazısında bunu bir rüya olarak belirtmesi belki de gelecek tepkileri azaltma çabası olabilir. Yazısında özellikle en çok değişim öngördüğü alan, devlet ve toplum yaşamına hakim olan dindi. O'nun hayalindeki ülkede devlet ve toplum yaşamındaki dinin etkisi büyük ölçüde ortadan kaldırılmış ve insanların vicdanlarına indirgenmişti. Kanun ve kuralların belirlenmesinde, insanların giyim kuşamlarında ve yaşayışlarında çağın ve ihtiyaçların etkili olmasını en ideal anlayış olarak görmüştür.

II. Meşrutiyet döneminden itibaren yazılarının en önemli ve süreklilik içeren konusu İslam dininin kuralları, kanunları, topluma olan etkileri, ibadet biçimleriydi. İlk yazısından başlayarak, 191214 yılları arasında başta İçtihad olmak üzere yazdığı dergilerde, İslam dininin uygulamalarını eleştiri konusu ederek, değiştirilmesi gereken kısımları ve neler yapılması gerektiğini açıklamıştır.

Kılıçzade Hakkı'nın hayatı boyunca en çok mücadele ettiği kesim kendi deyimiyle "sahte softalar ve dervişler" ve "batıl inançlar"dır. Onları toplumu cehaletine neden olan ve aydınlanmadan uzak tutan kesim olarak gördüğünden "cihad" ilanını farz görmüştür. Bu mücadele sonunda halkın "nur ile zulmü" ayıracağından, bu yolda İslamı ve ve İslam vatanını yaşatmak isteyen genç ve aydın fikirlileri, silahları olan kalemi ellerine alıp yazmaya çağırmıştır. Mücadele sonunda kazanılan zaferin bilim ve fen olacağını ileri sürmüştür. Kılıçzade Hakkı'ya göre; tarihsel süreç içinde padişahları yanlış yollara sevk eden, yenilikçi padişahları yeniçerilere teslim eden, idarenin zorbalıklarını teşvik eden, matbaada Kur'an'ın basılmaması için yobazları galeyena getiren, cehaleti besleyen, akla ve bilime karşı çıkan, hep bu softalar ve dervişlerdir. Onlar halkın İslam dinini ve medeniyetini tam olarak öğrenmesine engel olarak, gelişmeye, medenileşmeye ve Müslümanların Hristiyanlar tarafından aşağılanmasına neden olmuşlardır; onlar yüzünden Batıdan geri kalınmış, eğitime önem verilmemiş, ahlak ve maneviyatı mahvedilmiş, hurafeler din kisvesi altında sunulmuştur. İnsanları cehennemle korkutmuşlar ve İslamı korku dini haline getirmişlerdir (K1lıçzade Hakkı, 1329:17-27).

Kılıçzade Hakkı, ulemayı üç sınıfa ayırmıştır. Sayıları fazla olmayan, faaliyetlerini planlı yapan ilk gurubun, hareketi yönettiği kanaatindedir. Onları fesat ve iki yüzlü olarak nitelendirir. Cahil ulemadan oluşan ikinci guruptakilere softa adını vermiştir. Sayıları pek çok olan bu grubu İslam dünyasının cahil ve geri kalmasından sorumlu tutmuştur. Birinci grubun hazırladığ 1 faaliyetleri gerçekleştirenlerin ikinciler olduğunu vurgulamıştır. Hayat boyu da onlarla mücadele etmiştir. Hakiki ulemedan oluştuğunu belirttiği üçüncü grup ulemanın ise, çok az sayıda olduklarından çoğu kez seslerini bile çıkaramadığını savunmuştur (Kılıçzade Hakkı,1329:4-5). Ulema içinde çoğunluğa sahip olan softaları, Müslüman dünyasının geri kalmasından, dinin özünden uzaklaştırılıp hurafelerle doldurulmasindan sorumlu tutmuştur.

Softaların yetiştiği mektepler olarak gördüğü tekke ve zaviyelerin de geçmişte büyük düşünürler yetiştirmiş olmalarına rağmen cahil ve bilgisiz yobazların elinde kaldığından niteliklerini kaybetmişler ve zararlı hale gelmişlerdir. Toplumu tembelliğe, cehalete sevkederek, dini de çağdışı düşünceler ve hurafelerle doldurarak özünden uzaklaştırmış olduklarını ileri sürmüştür. Bu grup 
ortadan kaldırılırsa dinin de boş inançlardan ve hurafelerden kurtulup, özündeki akılcılığıyla toplumun ilerlemesine katkı sağlayacağını vurgulamıştır (Kılıçzade Hakkı, 1329:27-29).

Softalığın kadınlığın ilerlemesine düşman olduğunu ileri sürmüştür Buna kanıt olarak softaların kadınlar konusundaki görüşlerini ortaya koymuştur. Softalar, kadınların okuyup yazamayacağını, serbest olamayacağını savunuyorlardı. Onlara göre kadınların namaz için süreleri ezberlemesi yeterli sayılırdı. Hayvan nasıl ahırda bağlıysa kadının da evde öyle bağlı olması softaların arzusu olduğunu belirtmiştir. Kılıçzade Hakkı, İtikadatı Batılaya İlanı Harb, 1329, 8-9). Bu görüşlerin amansız düşmanı olduğunu belirterek, kadının insan olduğunu akıldan çıkarılmaması gerektiğini vurgulamıştır.

Kılıçzade hayatını softalarla ve şeyh ve dervişlerle mücadele etmeye adadığını, onu bu mücadeleden kimsenin çeviremeyeceğini, dili ağzında kalem elinde olduğu sürece yazacağını ifade etmiştir. Cumhuriyet döneminde de Hür Fikir gazetesindeki yazılarıyla savaşını sürdürmüştür.

Kuran'1, dinin saadeti üzerine alınmış bir sosyal kanunlar bütünü olarak nitelendirerek, Allah tarafından manevi kurtuluşu müjdelemek için verilmiş bir berat olduğunu savunmuştur. Dolayısıyla Müslüman olmanın onuruyla dünyaya önem verdiklerini belirtirken, İslamın diğer dinlerden farklı olduğunu vurgulamıştır: "İ̀lam Yahudilik gibi maksur değildir. İslam Hristiyanlık gibi zelil değildir. Bir yanağına vurana ötekini çeviremez. İslam ulvîdir, metindir, izzetlidr, bu itibarla kâinata hakim olmak isti'dadına haizdir. O isti'dadını göstermek için kendisini medeniyeti hazıranın bütün vesaitiyle techiz etmek isteriz..." (Kılıçzade Hakk1,1329:10-11).

İslamın peygamberi Muhammed'i deha olarak kabul eder ve en büyük mucizesinin aklı ve kitabı olduğunu savunmuştur. O'nun başka bir mucize aramadığını hatırlatarak, softaların iddia ettiği gibi mucizeleri ve doğa üstü güçlerin olmadığının altını çizmiştir. Kuran'ın gerçekte herşeyi içine aldığını belirtmekle birlikte dinin temeli olan kelime-i şahadet dışında hüküm belirten ve kural koyan bütün ayetlerin zaman ve yer ile uygun olarak değişmesinin gerekli olduğunu savunmuştur. Daha önceki içtihadların geçerliliğini yitirmiş olduğundan uzun zamandır dinin yeni gelişen veya ortaya çıkan durumlarla ilgili İslam alimlerinin yorum getirmemesini eleştirmiştir (K1lıçzade Hakk1,1329:1213).

Meşrutiyet döneminde içtihad kapısının kapalı olmasını İslam dünyasının geri kalmasını ve dinin özünü yitirmesinin temel nedenlerinden biri olarak olarak görmüştür. Bunun sonucu olarak da sadece dinde hurafelere teslim olmak değil, İslam günlük hayatın her alanını kapsadığından, her alanda geri kalmaya neden olmuştur. Bu durumdan kurtulmanın tek yolu olarak "medeniyeti hazıra" olan Batı uygarlığını "dini, milli, ahlaki ve örfün” dışında her şeyi Batı'dan almayı göstermiştir.

Kılıçzade Hakkı, cumhuriyetin ilanından hemen sonra şer'i kanunların yürürlükte olması karşısında üslubunu sertleştirmiş̧tir. Osmanlı döneminde yürürlükte olan şerî kanunları, "Arabistan'ın yaban çöllerinde binlerce yıl evvel çıkan" ve ülkemizde de en yüce yerde durma "küstahlığında bulunan" bir taassubun hayal ürünü olan dar çerçeveli kanunlar olarak adlandırmıştır. Bu kanunların ne uygarlığın gereğini, ne de sosyal yaşamın ihtiyaçlarına cevap vermediği için kaldırıldığını savunmuştur. Basit düşünceli birkaç adamın veya hocaların safsatası olarak nitelendirerek, asırlar boyunca Türk halkının bu kanunlarla kasıp kavurulduğunu ileri sürmüştür (Hür Fikir, 2 Kanunu Sani 1928:4). Bu kanunun kaldırılarak çağdaş uygarlığa uygun yeni kanunların kabul edilmesini büyük övgüyle karşılamıştır.

İslam dininin bir reforma ihtiyacı olduğu düşüncesi Kılıçzade başdan beri hep vardır. İlk yazılarında tam açıklıkla belirtmemesine rağmen onun dine, dini kurallara, din adamlarına yönelik sıklıkla getirdiği eleştirileri buna kanıt gösterilebilir. Eğer reform yapılmazsa, İslamın ve Kur'an'ın gerçeklerinin tam olarak ortaya çıkarılamayacağı görüşündedir. Medeniyeti hazıra olarak ifade ettiği Batının Hristiyan dinine mensup olması, İslam dünyasının kontrolleri altına almalarını sağladığı 
hatırlatmıştır. Müslüman ülkelerin büyük bir kısmının geri ve çağdışı olması sebebiyle, Batı dünyasında İslamın ilerlemeye engel olduğu algısını yarattığına dikkati çekmiştir (Akman, 2012:65).

Bu reform düşüncesinde Müslümanlar için mezhep birliğinin sağlanmasını da öngörmüştür. Büyük kısmının "sefil ve zelil”" yaşadığı İslam aleminde, farklı mezheplerin olmasını doğru bulmamakta ve birleşmelerinden yanadır. Bu mezheplerin kurucularını İslam dini bilimleri, sahip birer alim olarak kabul etmektedir (Kılıçzade Hakk1, İçtihad 4 Temmuz 1329:1539-1541).

Hilafetin Osmanlıya geçmesi sırasında farklı cins ve mezheplerden pek çok niteliksiz kişilerin başkente koştuklarını, kendileriyle birlikte “Arap'ın Acem'in beni İsrail'in” inanç namına ne kadar hurafe varsa getirdiklerini ileri sürmüştür. Böylece din diye kendi inançlarını empoze etmişlerdir. Kılıçzadeye göre; akıl ve mantığı temel alan Türk bilimi ise, yabancıların yönetimde etkin olmalarından sonra çöküşe başlamıştır (Kılı̧̧zade Hakkı, Hür Fikir 26 Kanunu Sani 1925: 1). O’na göre din ile ilgili olmayan Arap kültürünün pek çok unsuru, Türk kültüründe giderek daha çok yer kazanmıştır. Bu da İslam dininin inanç ve gelenekler bazında olumsuz etkilenmesine neden olmuştur. Batıcılık düşüncesi yanında Türkçü fikirlere de sahip olan Kılıçzade Hakkı, reform hareketiyle birlikte İslam inanciyla ilgili olmayan, sonradan eklenen ve dini olumsuz etkileyen unsurların temizlenmesini savunmuştur

İslamda reform yapılmasını tüm Müslümanlar için hayati öneme sahip bir konu olarak gören Kılıçzade Hakkı, bu sürecin en başına içtihad kapısının açılması ve bir daha kapanmamasını koymaktadır. Dinin asli hükümleri dışında zaman ve mekan ile uyumlu değişiklikler yapılabileceği ve yaşamsal öneme sahip olduğu, mevcut olan kanunların ve uygulamaların büyük bir kısmının zamana uygun olmadığından içtihad yoluyla yeniden düzenlenmesini savunmuştur. Onun reform programında mezheplerin birleştirilmesi düşüncesi de mevcuttur. O Hanefi, Şafi, Maliki ve Hanbeli gibi önemli din alimlerine büyük saygısı olduğunu belirtmekle birlikte, onlar kadar yetkin ve onların yerini alacak İslam alimlerinin yetişeceğine de inancı tamdır (Kılıçzade Hakkı, 1329:10-11).

Dinin bir çıkar ve iktidar aracı olarak kullanıldığını, mezhepler arası mücadelenin İslam dünyasına zarar verdiğini ve mezheplerin dünya işleriyle ilgili olduklarını belirtmiştir. Bir çok mezhebin hadis ve Kur'an'dan ibaret olduğu fikrindedir (Kılıçzade Hakkı, İçtihad 4 Temmuz 1329:1540). Bu görüşlerini "Pek Uyanık Bir Uyku” başlıklı yazısnda da görüleceği gibi ve İslam dünyasının güçlenmesi için dinde sonradan ortaya konulan mezhep farklılıklarının kaldırılması yolundaki görüşlerini sıklıkla yinelemiştir.

Kılıçzade Hakkı'nın dinde reform için en önemli unsurlardan biri, tesettürün kaldırılması ve kadının özgürleştirilmesidir. Her iki kelimeyi birbirinden ayırmanın mümkün olmadığını belirten Kılıçzade Hakkı, hem kadının üzerindeki baskıların ve yasakların kalkmasını savunan ve yazdığı yazılarla kamuoyu oluşturmaya çalışan en önemli yazarlardan biridir. O'na göre kadın ve erkek arasında üreme organlarının farklı olması dışında bir fark yoktur. Ayrıca iki cinsin ayrılması da söz konusu olamaz. Birlikte olmalarının amacı nesillerini devam ettirmektir. Tesettürün gayesinin, kadını sıkı sıkı sarıp "ucube”ye çevirmek değil, iffetini korumak olarak açıklamaktadır. Bununla birlikte tesettürün zararının, yararından daha çok olduğunu ileri sürmüştür. Tesettürün, kadınların hayatını ve sağlığını bozduğunu, onun cahil kalmasına neden olduğunu ve ahlâken yozlaştırdığını savunmuştur. $\mathrm{Bu}$ üç önemli zararın bir milleti kökünden devirmeye yeteceği kanaatindedir. Özellikle cehaletlerinin derecesinin ürkütücü olduğunu ve çocukları bu koşullar içinde büyüttüklerini düşününce, toplum için tehlikenin daha net ortaya çıktığını ifade etmiştir. Cehaletin tek nedeninin tesettür olmadığının da farkında olduğunu da belirtmiştir (Kılıçzade Hakkı, 1329:130-134).

O’na göre; tesettürün ahlâki ve siyasi olmak üzere toplumsal yaşama iki büyük olumsuzluğu da söz konusudur. Ahlaki kötülüğü olarak erkekleri oğlancılığa, kadınları ise seviciliğe yönlendirmesidir. Siyasi olarak da fethettiğimiz yerlerdeki unsurlarla iletişim kuramayıp, oralarda yabancı gibi durulmasına ve ilk yenilgide de göç edilmesine sebebiyet vermesidir (Kılıçzade Hakkı, 
1329:135-136). Ahlâki kötülüğünü mantıksal olarak anlamak mümkün olmasına rağmen, ikinci olarak belirttiği fethedilen yerlerde yabancı kalmayı tesettüre bağlamak çok mantıklı gibi gözükmemektedir.

Kilıçzadeye göre tesettürün olumsuz etkileri bir yana mevcut uygulama ne İslami kurallara uygundur ne de insanın doğasına uygundur. İslamiyete tabi olmayan hiç bir kuralın dine ve dolayısıyla insan hayatına giremeyeceği görüşündedir. Ayrıca bir toplumun sağlıklı biçimde yaşaması ve gelişmesi için aile hayatının iyi olması, ev aile bağlarının güçlü olması gerekmektedir. O’na göre birbirini görmeden, tanımadan evlenen insanların sağlıklı bir aile olması neredeyse imkansız olduğundan, hali hazırda Türk toplumunda aile vardır demek söz konusu değildir. Görücü usülüyle tam olarak bir aile kurulamıyacağı görüşünde olan Kılıçzade, bu usulun ortadan kaldırılmasını savunmuştur. Zararları göz önüne alındığında tesettürü, dini veya milli bir gelenek olarak devam ettirmenin bir anlamı olmayacaktır. Kadınların eğitilmesini, dinin baskılardan kurtarılmasını ve özgür olmalarının sağlanmasını zaruri bulmaktadır. İlerlemek ve çağcıl bir toplum olabilmenin gereklerinin en başında gelenlerinden biri, kadını ve erkeği eğitilmiş bir toplum olmak olduğunu israrla savunmuştur (Kılıçzade Hakkı, 1329:137-139).

Tesettürün kaldırılmasının birden bire değil, zamana yayarak ve içtihad yoluyla yapılmasından yanadır. Böylece sorun hissedilmeden aşılmış olacaktır. Tesettür ve kadın politikalarından yola çıkarak, amacı olmayan ve cahilane biçimindeki taassubun, Osmanlı'yı geri bırakan nedenlerin başında geldiğini vurgulamıştır.

Kılıçzade Hakkı'ya göre; hiçbir dinin kendine has bir kıyafeti yoktur. Bundan hareketle tesettürün kaldırılmasını savunmasının yanı sıra Müslüman din adamlarının sarık sarmasının, cübbe giymesinin dinle hiçbir ilgisi olmadığını ileri sürmüştür. Peygamberin zamanda bunların olmadığını, bugün bile Arapların sarık sarmadığını, bu kıyafetlerin Osmanlı döneminde giyilmeye başlandığını belirterek, peygamberin hiç giymediği kıyafetlerin "sünnet" olduğu gerekçesiyle, Diyanet İşleri Başkanı'nından köy imamına kadar giyilme geleneğine ağır eleştiri getirmiştir. Peygamberin dini kıyafet adı altında hiçbir kıyafet giymediğini, o dönemde kendi ülkesinin coğrafi koşullarına uygun olarak giyindiğini, basit fakat gösterişsiz olan kıyafetlerinin o dönemde ihtiyaçlarını karşılayacak nitelikte olduklarını belirtmiştir. "Peygamber bugün mebus olsaydı malum olan zarafeti terbiyeye binaen Avrupalı gibi giyinmekte hiç tereddüt etmezdi" diyerek, dinleri ve insanlığınin özel kıyafet biçimlerinin olmadığını savunmuştur. Allahın fesle, sarıkla, şapkayla, kıyafetle hiç alakası olmadığını sıklıkla vurgulayarak, esas olanın "yüksek bir insan ve iyi bir Türk" olmak olduğunu vurgulamıştır (Kılıçzade Hakkı, Hür Fikir, 11 Mayıs 1925:1)

KIlıçzade'ye göre; din adamlarının olsun veya tüm kadın-erkek Müslümanlar olsun, zamanına ve bulunduğu coğrafyaya göre ihtiyaçlarını karşılayacak biçimde giyinmelidirler. Kıyafetleri veya başlıkları dinler için kutsal olduğunu savunmanın söz konusu olamayacağını dile getirmiştir. Dinde şekle verilen önemin, özün kaybedilmesine veya önemsiz kılınmasına neden olacağı görüşündedir. Bu konudaki tartışmalar, sarığın ve fesin yerine şapkanın getirildiği Şapka Kanunu çıkarıldığı sıralarda yoğunlaşmıştır.

1928 yılında İstanbul Üniversitesi'ndeki bir grup profesör tarafindan hazırlanan ve kamuoyuna açıklanan reform programına (Jaschke,1972;40) en çok destek verenlerden biri olmuştur. 15 yıldır dini kurumlara ve onları tutanlara başlattığı mücadeleyi hatırlatarak, "İslam dininin esasatına olmasa bile eşkâline bir inkılabın mukarrer" olduğunu yıllar öncesinden gördüğünü belirtmiştir. Müslüman dünyasında bunu yapabilecek tek topluluğun da Türkler olduğu kanaatindedir. Diyanetten başlayarak bütün kurumların bu sürece katkı yapmasını gerekli görmüştür. Bugün kimsenin bir ay oruç tutamayacağını, beş vakit namaz kılamayacağını, temin bir Müslümanın herkesin ayağını bastı̆g 1 yere yüzünü sürmeyeceğini ileri sürerek, reformun dinin ibadetlerini de kapsaması gerektiğinin altını çizmiştir. O'na göre reformun bir an evvel yapılması "bizzat dinin menfaatinedir" ve "bizzat dindarlar yapacaklar, bu vazife onlara gider” (Kılıçzade Hakk1, Hür Fikir, 2 Temmuz 1928:1). 
Din reformu adıyla kamuoyuna duyurulan bu taslak, Kilıçzadeyi gerçekten heyecanlandırmıştır. Reform taslağında yer alan ve yapılması savunulan bir çok değişiklik yıllardır onun savunduğu düşüncelerle büyük benzerlik göstermiştir. Ancak gelen tepkiler üzerine Milli Eğitim Bakanlığ konuyla bir ilgisinin olmadığını açıklaması ve raporun rafa kaldırılması da bu kez hayal kırıklı̆g 1 yaratmıştır. Ancak yine de laik bir devlette er ya da geç mutlaka reformun kaçınılmaz olacağını ve bunun için biraz zamanın gerektiğini düşünmekteydi.

\section{Laiklik Düşüncesi}

"Dinim yaşamaktır" sözünü, Hür Fikir Gazetesi’nin yayınlandığı ilk günden beri isminin hemen altına yazan Kılıçzade Hakkı, II. Meşrutiyetten Cumhuriyete hatta tüm yaşamı boyunca laiklik savunucusu olmuştur. Laiklik anlayışının ne olduğunu açıklayarak, laikliğe dinsizlik olarak bakıldığı bir zamanda bu görüşlerini cesurca ortaya koymuştur. Dini dergilerin ve yazarların sıklıkla eleştirilerine uğramasının yanı sıra İttihat ve Terakki iktidarının da baskısına uğramıştır. II. Meşrutiyet dönemindeki yazım hayatı kısa sürmüş ve Çanakkale'ye gönderilerek İstanbul'dan uzaklaşması sağlanmıştır.

Din konusunda savunduğu görüşleri nedeniyle sıklıkla dinsizlikle suçlanmıştır. Kılıçzade bu suçlamaları yapanları "oldukları gibi görünmeye cesaret edemeyenler ile dini alet-i intifa (çıkar aracı) makamında kullanmak isteyenler" olarak belirtmiştir. Dini alçaltmak gibi bir amacı olmadığını, halkı batıldan kurtarıp, hakka ve gerçeğe yönlendirmeye çalışıtı̆̆ını ve cahil ulemanın halka telkin etmeye çalıştığ 1 hurafelere ve batıl inançlara gerçek dinde yer verilemeyeceğini savunmuştur. Allah'ın varlığına, birliğine, bütün kuvvetlere sahip olduğuna; koyduğu bozulmaz kanunları insanları ve sonsuz evreni yönettiğine inandığını belirtmiştir. İnsanlara akıl vererek onları özgür bıraktığını, insanları aydınlatmak için deha olarak nitelendirdiği peygamberler gönderdiğini de savunmuştur (Kılıçzade hakk1, 1329/ 1913:8-9)

"Ne İstiyoruz?" başlıklı makalesinde dünya ve ahiret işlerinin birbirinden ayrılmasını istediklerini belirtmiştir. Bu basit ve hak olarak gördüğü isteğini güçlendirmek için, ulemanın görevinin sadece halka doğru yolu göstermek olduğunu, içtihad kapısının açılarak dini kuralların zamanla ve ihtiyaçlara uygun hale getirilmesini, tekkelerin mekteplere dönüşmesini, şeyhlere ve dervişlere toplumun ihtiyacı olmadığı, cahil şeyhler ve dervişler yerine Darülfünun öğretim görevlilerini görmek istediklerini ifade etmiştir (Kılıçzade Hakkı,1332:19-20). Söz konusu yazısında laikliliğin gerekliliğine toplumu ikna etmek için dinsel kanıtlar ve örnekler vermiştir. Öncelikle İsa Peygamberin "Allaha ait olanı Allah'a, Kayser'e ait olanı Kayser'e veriniz" emrini hatırlatmıştır. Hıristiyan dünyasında laikliğin ortaya çıkışına dayanak oluşturan bu sözden sonra Müslüman dünyası için de, Muhammed Peygamberin "dünya işlerinde siz benden alimsiniz" sözünü gerekçe göstermiştir. $\mathrm{Bu}$ sözler ortadayken, medrese ve tekkelerde kafaları bilim ve fen yerine hurafelerle doldurulan softaların, dünya işlerini ve insanları yönetmesinin söz konusu olamayacağı görüşündedir. Kılıçzade, dinin vicdana ait olduğunu, dünyevi işlere karıştırılmamasını ve ulemanın da dünyevi yönetimden uzaklaştırılmasını öngörmüştür. O kadınlarda tesettürün kaldırılarak serbestlik verilmesini, toplumu insanlık aleminden ayıran bütün bağların koparılmasını da laikliğin gereklerinden saymıştır (Kılıçzade Hakkı,1332:31-33).

1914 yılından beri yazmadığı İçtihad Dergisi’ne, 1923 Şubat ayından itibaren yeniden yazmaya başlamıştır. 1924 yılının Ocak ayında İzmit'te yerel bir gazete niteliğindeki Hür Fikir Gazetesi'nde, din ve laiklikle ilgili en sert yazılarını yazmış ve Türk devrimini bütün gücüyle desteklemiştir. Hür Fikir yerel bir gazete olmasına rağmen, Kılıçzade’nin kişiliği ve görüşlerinden dolayı etkisi ulusal çapta olmuştur. Özellikle dini referans alan yazarlar ve dergiler, yazılarını yakından takip ederek eleştirmeye devam etmişlerdir. Başta Kocaeli Müftüsü ve vaizleri tarafından olmak üzere, dini aşağıladığı ve halkı dinsizliğe sevk ettiği gerekçesiyle sıklıkla mahkemeye verilmiştir. Ancak cumhuriyet döneminde mahkumiyet almamış ve hepsinden beraat etmiştir. $\mathrm{Bu}$ gazeteyi çıkarmasını Gazi Mustafa Kemal'in istediğini belirtmesi, akıllara bazı soruları getirmektedir. 
Acaba, Mustafa Kemal, laiklik yolunda değişimler gerçekleştirilmeden önce Kılıçzade Hakkı'nın yazıları aracılığıyla kamuoyuna tartışmaya açılmasını veya kamuoyunun konuyla ilgili tepkilerini öğrenmesini sağlamaya mı yönelik bir girişim olarak değerlendirilebilir mi, sorusu ilk akla gelendir.

1923 İzmit basın toplantısında, devletin dini olup olmayacağı ve dinin yönetimde olup olmayacağı konusunda istediği cevabı alamayan Kılıçzade Hakkı, önce cumhuriyetin ilanı arkasından da Hilafetin kaldırılmasıyla yeni devletin yolunun laiklik ve demokrasi olduğunu görmüştür. 1925 yılı başlarında çıkan Şeyh Sait isyanı, O'nun yeniden şeyhlere ve softalara savaşını gündeme getirmesine neden olmuştur. Softaların ve hocaların cumhuriyete sadık taraftar olmayacaklarını savunarak, TBMM'nin, Osmanlı'dan arta kalan bu teșkilatı bir an evvel kaldırmasını ve din ve dinin yönetiminin halka devir ve teslimini istemiştir. Halkın kendi hatibini ve vaizini seçmesini teklif etmiştir (Kılıçzade Hakk1, Hür Fikir, 9 Mart 1925:1).

Gazi Mustafa Kemal'in öncülügündeki adım adım uygulamaya konulan devrimleri ve özellikle de laikliğe gidiş sürecini övgüyle izlemiştir. Semavi kanunların toplumun ihtiyaçlarını ve çağın gereklerini karşılamadığı; toplumun ihtiyaçlarını karşılayacak çağa uygun yasalar yapılmasını, "bir cumhuriyet idaresinin layık olmak zorunda" olduğunu savunmuştur (Kılıçzade Hakkı, Hür Fikir, 18 Mayıs 1925;1). Toplum ve insan haklarına uyulması koşuluyla kişilerin özel işlerinde tamamen serbest bırakılmasını savunarak, laikliği sadece din ve devlet işlerini ayırmak olarak görmeyerek, bireyin tüm hayatını içine almasını istemiştir. Bu görüşü tutarlı biçimde savunarak laikliği ideolojiye dönüştürmeye çalıştı̆ğ söylenebilir (Pekdoğan, 1999:235).

Cumhuriyetin ilanının arkasından hilafefetin kaldırılması Kılıçzade Hakkı'yı laiklik yolunda cesaretlendirmişti. Abdullah Cevdet'in “...Halk Fırkası hükümeti laakal otuz seneden beri geceli gündüzlü gördügümüz tatlı rüyaların çoğunu ayniyle vaki kılan yegane hükümettir” sözlerinden (Abdullah Cevdet, Hür Fikir 1 Temmuz 1925;3640) ve Süleyman Nazif' in 7 Nisan 1924'te yolladığ1 mektubundan (Süleyman Nazif, Hür Fikir,18.4.1924:1) da anlaşıldığı gibi, Kılıçzade'nin düşlediği devlet ve toplum yapısına uygun bir değişim süreci söz konusuydu.

Tekke ve zaviyelerin kapatılması ve şapka devriminin yapılması, cumhuriyet yönetiminin memleketi hurafelerden temizleyerek sonsuza kadar yaşatmak konusundaki kararlılığ ortaya koyması olarak yorumlanmıştır (Hür Fikir, 7 Eylül 1925:1). 1926'da Türk Medeni Kanunu'nun kabul edilmesi de laik bir devlet ve toplum sürecinde önemli bir aşamadır. Kılıçzade bir yandan gazetesinde laiklik yolundaki değişimlerden övgüyle bahsedip alkış tutarken; diğer yandan Diyanet İşleri Başkanı Börekçizade Rıfat'tan başlayarak, müftü, imam ve vaizlerin takipçisi olmuştur. Rıfat Efendi'ye sık sık yazılı sorular vererek, laiklik anlayışını, Kuran'ın Türkçeleştirme çalışmasını, doğaüstü güçlere olan inancını sorgulamaya çalışmıştır (Hür Fikir,19 Mayıs 1926:1) Çoğunlukla kendisi gibi olmasa bile resmi ideolojiyle uyumlu yanıtlar almıştır. Bu nedenle gazetesinde Diyanet İşleri Başkanı'na yönelik sert eleştirileri fazlaca görmek mümkün değildir.

Bununla birlikte din adamlarına bakışı genelde olumsuzdur. O, 1925'te din görevlilerini halkın kendisi seçmesi gerektiğinden söz etmiştir. Halk, yapacağ 1 seçimle imamını ve vaizini kendi istediği kimseyi yapabilmeliydi... Bu öneri hayata geçirilememişti ama laiklik yolunda dev adımlar atılmaya devam ediyordu. Dinin giderek toplumun vicdanına yerleştirilmesi süreci hız kazanmıştı. Kılıçzade bu dönemde müftülüklerin kaldırılması konusunu gazetesinde gündeme getirmeye çalışmıştır (Hür Fikir, 9 Ocak 19281).

Esasen Diyanet İşleri de dahil olmak üzere ülkedeki bütün dini kurumların kaldırılmasını istemiștir. O'na göre devletin din ile hiçbir bağı kalmamalıydı. Hele hele geçmiş dönemin mirası softalara hükümet göz açtırmamalıydı. Zira yüzyıllardır biriktirilen cehaletin etkisini ortadan kaldırmak zaman işiydi. Bu nedenle halkın aydınlanmasını olumsuz etkileyecek etkenler bir an evvel ortadan kaldırılmalıydı. 
Kılıçzadeyi cumhuriyet dönemi içinde en mutlu eden olaylardan biri, 10 Nisan 1928 tarihinde Teşkilatı Esasiye'de yapılan değiş̧iklikle "devletin dini, din-i İslamdır" hükmünün anayasadan çıkarılmasıdır. Basit bir ifadeyle Türk'ün tam hürriyeti sağlanmıştır. $O$ güne kadar yapılanların sonuçlandırılması olarak da nitelenebilecek bu gelişmeyi sabırsızlıkla beklediğini yazmıştır. "Layiklik İşte Bu Demektir" başlığıyla kaleme aldığı yazıda laikliğin temellerini dinlerden aldığı referanslarla kurmaya çalışmıştır (Kılıçzade Hakk1,Hür Fikir, 16 Nisan 1928:1).

"Hayır ve şerrin önünü açtı. İntihab et! (Musa peygamber-Tevrat)

“Allahınkini Allaha devletinkini devlete veriniz. İsa peygamber-İncil

"Biz dünyayı kabiliyetli insanların idaresine tevdi ettik (Muhammed Peygamber Kuran)

"Dinler pek çoktur, insanlar ise kardeştirler. (Konfüçyus)

“Akıldan daha üstün hiçbir şey yaratmadım” (Hadis-i kudsi)

Kılıçzade, dinlerin peygamberlerin sözlerinden yola çıkarak laikliğin gerekliliğini ortaya koymaya çalışmıştır. Bu zamana kadar laiklik yolunda verdiği mücadele nedeniyle dine hakaret ettiği suçlamasıyla hakkında pek çok davanın açıldığını yazmıştır. Amacının dine zarar vermek değil, işlevini çoktan yitirmiş bir kurumun yıkılma sürecini hızlandırmak olduğunu belirtmiştir. Anayasada devletin dinin kaldırılmış olması, "her efrad nakil yerine ilim ve aklı hakim kılacak"tır. Türkiye artık hür bir ülke haline gelmişti. En büyük isteğinin gerçekleştiğini ve artık isteyecek bir şey kalmadığını belirten Kılıçzade Hakkı, dinin devlete egemen olmasının bütün olumsuzluklarını gördüğü için, din ve dünya işlerinin ayrılmasını istediğini ifade etmiştir (Kılıçzade Hakkı, Hür Fikir, 16Nisan 1928:1).

K1lıçzade laikliğin anlamını şu ifadeleriyle açıklamıştır: "Biz Türkler bugün manen ve maddeten kamil bir hürriyete kavuşmuş bulunuyoruz. Bundan sonra hiçbir hükümet benim vicdanıma müdahale etmeyecektir. Ben Allah istediğim şekilde ibadet edecek hür ve medeni bir insan olmaya çalışacağım".

Kılıçzade Hakkı, yıllardır açıklamaya çalıştığı gibi laikliğin herşeyden önce özgürlük olduğunun altını çizmiştir. Bununla birlikte dinsiz ve dinsizlik anlamına gelmediğini vurgulamıştır. Laikliğin kabul edimesini "medeniyetin peygamberi” olarak isimlendirdiği Mustafa Kemal'in çabasını da minnet ve şükranla anmıştır (Kılıçzade Hakkı, Hür Fikir;16 Nisan 1928:1).

Kılıçzade Hakkı, laiklik düşüncesinin felsefi bir açılımını yapmamıştır. O'nun için din adamlarının dünyevi işlerden uzak tutulması ve dinin bir vicdan işi haline getirilmesidir. O'na göre, laik bir yönetimde vicdan özgürlügü tam olarak sağlanmıştı.

Kılıçzade Hakkı'nın tam olarak düşündüğü laiklik artık gerçekleştirilmiştir. Esasen O’nun rüyasının neredeyse tamamı Atatürk döneminde gerçekleştirilmiştir. Ancak laik sistemin yerleştirilmesi ancak zamanla mümkün olacaktır. Bu durumun farkında olan Kılıçzade, 1931 seçimlerinde Muş milletvekili olarak parlamentoya girdikten bir süre sonra gazetesini kapatma kararı almıştır. Gerekçesi de milletvekili olarak yoğun çalışma temposu olmasındandır. Bununla birlikte amaçları gerçekleşmiş biri olarak, amaç boşluğu da yaratmış olabilir. Yazmak için belki de bir nedeninin kalmadığını düşünmüştür. Nitekim parlamentoda milletvekili olarak görev yaptığı beş dönem boyunca pek yazı yazmamıştır.

\section{Sonuç}

II. Meşrutiyet dönemi Batıcılık düşüncesini savunan aydınlar içinde tartışmalara konu olan isimlerin başında hiç kuşkusuz Kılıçzade Hakkı gelmektedir. Çocukluk ve gençlik yıllarını Manastır'da geçirmesi O'nun batıcılık ve din düşüncelerinde etkili olmuştur. Askeri okulda okumuş ve subay olarak orduya katılmış olanlar içinde positivizmi benimseyenlere sıklıkla rastlanmasına rağmen, 
biyolojik materyalizmi ve darvinizmi benimseyen az sayıda aydınlardan biridir. O'nun belki de bütün yaşamında derin izler bırakan ve belirleyici etkiye sahip olan bu felsefi düşünceleridir.

Kılıçzade Hakkı, 1912 yılına kadar matbuat yaşamında pek tanınan biri olmamıştır. İlk Balkan savaşının kaybedildiği dönemde yazmaya başlaması, ağır yenilginin Osmanlı aydınında yarattığı derin travmanın etkisiyle olabilir. Avrupa topraklarından Anadolu içlerine kadar sürülen Türkler için artık gidecek başka bir yer olmadığından, tek .çare radikal adımlarla çöküşün önlenmesi ve çağcıl bir devlet haline getirilmesiydi. Bunun nasıl yapılacağı konusu duraklama ve gerileme döneminden itibaren devlet yöneticilerin, aydınların en çok sordukları soruydu. Bir kısmı sadece manevi uygarlığın alınmasını, bir kısmı ise maddi ve manevi uygarlığın bir bütün olarak çağın en gelişmiş ülkelerini oluşturan Batı'dan alınması gerektiği düşüncesindedirler. Batı uygarlığının bir bütün olarak alınması gerektiğini savunan en önemli isimlerden biri olan Kılıçzade Hakkı da sadece bu düşünceyi yazıları aracılığıyla savunmakla kalmamış, aynı zamanda Batıcılığın programı olarak kabul edilen ve yayınlanan ilk yazısı olan "Pek Uyanık Bir Uyku" başlıklı yazıyı da kaleme almıştır. Bu nedenle II. Meşrutiyet döneminde Batıcılık düşüncesinin sistemli bir akım haline gelmesinde önemli rol üstlenmiştir. Kılıçzade Hakkı'nın önemli rolü vardı.

"Kılıçzade" lakabı dili ve kalemi keskin olduğundan dolayı İçtihad'ın yazım kadrosu tarafından kendisine verilmişti. Kılıçzade bu ismi çok sevmiş ve kendisine uygun bulmuş olmalı ki, önce lakap, daha sonra ise soyadı olarak hayatı boyunca kullanmıştır. II. Meşrutiyet döneminde savunduğu ve devletin kurtuluşu için Batıyı bir bütün almak gerektiği yolundaki görüşleri, İslamcı bir dergi olan Sebilürreşad'ın sıklıkla eleştirisine uğramış ve toplumun ihtiyaçları ve kültürel ortamıyla, gelenekleriyle diniyle uygun olmayan mantıksız düşünceler olarak değerlendirilmiştir. Oysa, görüsslerine bir bütün olarak bakıldığında insan ürünü olarak gördüğü dinin etkisinin ortadan kaldırıldığı bir toplum yaratma noktasında kendi içinde mantığının olduğu açıktır. Cumhuriyet'ten sonra gerçekleştirilen devrimlerde, O'nun savunduğu bir çok düşünce uygulama alanına taşınmıştır.

Kılıçzade, batılılaşma düşüncesinin temeline din düşüncesine bakışını koymuştur. Allah inancının varlığını sık sık yazılarında belirtmekle birlikte, dinin semavi kaynaklı değil, insan ürünü olduğu kanaatini taşımaktadır. O'nun genel olarak din ve özelde de İslam hakkındaki görüşleri, biyolojik materyalizm, darwinizm ve II. Meşrutiyet döneminde pek çok aydın tarafindan benimsenen pozitivist düşüncenin yoğun etkisi altındadır. Devletin çökmesini bireylerden başlayarak çözme konusu da O'nun hem batılılaşma hem de din konusundaki görüşlerine yansımıştır. Esasen din konusundaki görüşleri batılılaşmayı zorunlu kılıyor veya batılılaşma düşüncesi din konusundaki görüşlerinde belirleyici rol oynamıştır; karşılıklı bir etkileşim söz konusudur.

Kılıçzade Hakkı, en büyük mücadeleyi, cahil ulemaya karşı vermiştir. Hatta, "sahte softalara ve dervişlere" savaş açtığını yazdığı makalelelerle ortaya koymuştur. Materyalist düşünürlerin izlerini taşıyan ve dini, insanlığın tekamül evrelerinden biri olarak açıklamaları, geleneksel kesimlerin sert tepkilerine neden olmuştur. Allah'a inancı olduğunu ve her türlü kudrete onun sahip olduğunu belirtmesine rağmen, dört hak dinin kutsal kitaplarında insanın yaratılması ile ilgili yazılanlara inanmadığını belirtmiş ve eleştirmiştir. Dinlerin ortaya çıkışı konusunda yazdıkları da çok ses getirmiştir. Kılıçzade, dinleri peygamberlerin oluşturduğu konusunda ciddi iddialarda bulunmuştur. Dinin semavi olmadığını, peygamberler tarafından oluşturulduğunu savunmuştur.

II. Meşrutiyet döneminde yazdığı yazılar içinde kadın konusu özel bir yer tutmuştur. Kadınlara yönelik başta dinsel olmak üzere her türlü kısıtlamanın kaldırılmasından yanadır. Tesettürün kaldırılmasından başlayarak, kadınların ve erkeklerin eşit olması, birlikte eğitilmesi, sosyal yaşamda yer alması, görücü usulünün kaldırılarak eşlerini kendilerinin seçmesine kadar o dönemde radikal sayılabilecek taleplerde bulunmuş̧ur. Buna gerekçe olarak da, bir toplumun sadece bir kesimin kalkınmasının mümkün olamayacağını, kadın aracılı̆̆ı ile bir toplumun dönüştürülebileceğini göstermiştir. 
Yazıları nedeniyle sıklıkla yazılar yazdığı dergiler ceza almış ve kapanmıştır. Öyle bir hale gelir ki, çıkardığı veya çalıştığı her yayın kapatılınca İttihat ve Terakki hükümetinin O'na yazı yazdırmamadaki kararlığını görmüştür. Buna karşılık Kılıçzade de üst düzey yöneticilerin uyarılarına, hakkında açılan davalara ve harp divanında yargılanmasına rağmen yazma konusunda kararlılığını sürdürmüştür. II. Meşrutiyet dönemindeki din ve laiklik düşüncesi ve savunusu, ülke aydınlarının gündemine dinde reform düşüncesinin ve laikliğin sokulmasında önemli rol oynamıştır.

Yazım hayatından bir süre için kopan ve Muhacirun Müdürlügü̈nde memuriyetiyle yetinen Kilıçzade için yazmadan durmak pek mümkün olmamıştır. Çanakkale'den sonra gittiği İzmit, onun yeniden yazmaya başladığı yer olmuştur. Mustafa Kemal ile İzmit'te görüşen Kılıçzade Hakkı, cumhuriyetin ilanından başlayarak, rüya olarak nitelendirdiği ve gerçekleşmesini istediği ama gerçekleşebileceğine pek olanak vermediği değişimlerin bir bir gerçekleşmesini büyük keyifle izlediği yazdıklarından anlaşılmaktadır. Süleyman Nazif tarafından tebrik edilen Kılıçzade, devlet ve toplum yapısına laiklik ilkesi tam olarak yerleştirilene kadar, çıkarılan her kanunu, yapılan her uygulamayı yetersiz bulmuş ve hep bir sonraki adıma işaret etmiştir. 1928 yılında devletin dininin İslam olduğu maddesinin çıkarılması hakkındaki kanun kabul edildiğinde ise, laiklik işte budur diyerek sevincini ve özlemini dile getirmiştir.

Cumhuriyetle birlikte dinden çıkar sağlayan ve dini çıkar aracı olarak kullananlara göz açtırılmadığı için yazılarında bu kesimle mücadele çok yer tuıtmamıştır. Ancak Şeyh Sait İsyanı nedeniyle yazdığı yazılarda, bu kesimlerin asla cumhuriyetçi olamayacakları ve her firsat çıktığında yıkmak isteyeceklerini ileri sürerek, topyekün imha edilmesi gereğinden söz etmiştir. Kılıçzade, Diyanet İşleri Başkanlığı'nın ve müftülüğün olmasına ve bütçeden para harcanmasına karşıdır. O’na göre devlet kurumu içinde hiçbir şekilde din adamı ve din görevlisi çalıştırılmamalıydı. Ona göre bu laiklik ilkesinin gereğiydi.

Kılıçzade Hakkı yazılarında laiklikten ne anladığını II. Meşrutiyet döneminde tam olarak açıklamamış; sadece dinin devlet işlerinden ayrılması, kanun yaparken dinin referans alınmaması gerektiğini belirtmiştir. Cumhuriyet dönemindeki, laikliğin vicdan özgürlüğü demek olduğunu da vurgulamıştır. Dinin devlete karışmasına karşı olduğu gibi, devletin de dine karışmamasını öngörmüştür. Dini hiçbir kurumun devlet mekanizması içinde yer almamasını savunmuştur. Yerel veya ulusal nitelikte dinsel çevrelerden eleştiriye maruz kalmakla birlikte hakkında pek çok dini aşağılama ve küçültme suçlamalarıyla davalar açılması da bu görüşlerini etkilemiştir. Ancak bu davaların hepsinde beraat etmiştir.

Kuran'ın ve ibadetin Türkçeleştirilmesi görüşünü II. Meşrutiyetten beri savunduğu için, bu konuda yapılan çalışmaları desteklemiştir. Halk kendi dilinden dinini öğrenirse, cahil ulemanın O'nun istediği gibi yönlendiremeyeceği kanaatindedir.

Laiklik konusunda cumhuriyet hükümetleriyle anlaşamadığı veya aynı fikirde olmadığı tek konu devletin dine karışmaması/karışması konusundadır. Zira iktidar, dini de istediği gibi kontrol altında tutmak ve yönlendirmek istiyordu.

Kılıçzade Hakkı'yı iki ayrı dönemdeki din ve laiklik konusundaki görüşlerini karşılaştırdığımızda bir tutarlılığın söz konusu olduğu hemen görülmektedir. İlk dönemde baskılara ve yasaklara rağmen görüşlerini korkusuzca savunmaya devam etmiştir. Cumhuriyet döneminde istediği yönetim ve hukuk anlayışı zaten mevcuttu. Bu kez de dinsel çevrelerin eleştirisine uğramış olsa da görüşlerinden pek ödün vermemiştir. Hür Fikir Gazetesi yerel bir gazete olmakla beraber etkisi ulusal niteliktedir. Kocaeli üzerinden yerel bir pencere açarak, laik bir devletin oluşturulma sürecine katkıları yadsinamaz.

Kılıçzade, Cumhuriyetin gerçekleştirdiği bir çok yeniliği ilk yazan kişi olmakla beraber, siyasi iktidarla diyalogları pek göz önünde olmamıştır. Hatta Milli Mücadele döneminden itibaren mesafeli bir ilişki içindedirler. Hatta 1919 seçimlerinde İzmit’ten adaylığı da desteklenmemiştir. Bunda 
mütareke döneminde batıcı düşünceye sahip bazı isimlerin Hürriyet ve İtilaf ile ilişki içinde olması rol oynamış olabilir. Cumhuriyetten sonra Hür Fikir gazetesini Mustafa Kemal'in isteğiyle çıkardığını belirtmesi, iktidarın O'na olan ilgisini göstermektedir. Kılıçzade Hakkı, en başından itibaren devrimlerin en hararetli savunucusu olmasına rağmen, iktidar tarafından aynı biçimde taltif edilmemiştir. Laikliğin önemli ölçüde uygulama aşamasına konulduğu 1927'de milletvekili olmuştur. Görünüşe göre siyasi iktidar, batıcı ve dine yönelik radikal eleştirileriyle tanınmasından dolayı, en azından ilk zamanlar için kamuoyunun tepkisinden çekinmiş olabilir. Din ve laiklik ile ilgili değişimler başta olmak üzere cumhuriyet döneminde gerçekleştirilen pek çok değişimin fikir babası olmasına rağmen, Cumhuriyet dönemi düşün yaşamını etkileyen aydınlar arasında pek yer verilmemesi de bu çekincenin bir sonucu olabilir.

Kılıçzade Hakkı, cumhuriyet dönemi laikliğin uygulamalarından tam olarak memnun olmamış, devletin dinle tüm bağını kesmesi konusunda 1srarcı olmuştur. Muş milletvekili yapılmasından sonra gazetesini kapatarak yazım hayatından uzaklaşmıştır. Bunun kendi iradesiyle olup olmadığını bilemiyoruz. Bununla birlikte aktif gazetecilik hayatının sonlandığını söylemek mümkündür.

\section{KAYNAKÇA}

“Kılıçzade Hakkı Bey’in İki Mektubu” İçtihad, 10 Şubat 1923, s.3132-3134.

Abdullah Cevdet, "Kılıçzade Hakkı Bey Kardeşimize Açık Mektup", Hür Fikir 1 Temmuz 1925.

Akman, Zekeriya (2012), Kılıçzade Hakkı'nın Siyer Yazıcılı̆̆ı İle İlgili Görüşleri, Sakarya Üniversitesi İlahiyat Fakültesi Dergisi, Cilt: XIV, Sayı: 26.

Akşin, Sina (ed.)(2008), Türkiye Tarihi C. IV, Cem Yayınları, İstanbul.

Altıntaş, Ramazan (2008), "Batılılaşmış bir Doğulu: Kılıçzâde Hakkı ve Projesi”, Eski Yeni Dergisi, Say1 8, s.93-102.

Berkes, Niyazi (1975), Türk Düşününde Batı Sorunu, Ankara, Bilgi Yayınevi.

Çavdar, Tevfik (1981), "İleri Gazetesi'nde 1919 Seçimleri”, Amme İdaresi Dergisi, C. 14, S.2, s.1733.

Jaeschke, Gotthard (1972), Yeni Türkiye'de İslamlık, Ankara, Bilgi Yayınevi.

Kılıçzade Hakkı (1331), Akvamü's-siyer Münasebetiyle Son Cevap, Yeni Osmanlı Matbaası ve Kütübhanesi, İstanbul.

(1329), "İtikâdâtı Bâtılaya İlânı Harb”, Sancakciyan Matbaası, 1.tab.

_-“Azadamard Gazetesi Ser Muharrirliğine”, İçtihad, 4 Temmuz 1329;1539-1541.

“Bir Küçük Hatıra”, Hür Fikir, 24 Mart 1926.

“Cevab Yerine Dayak!”, Hür Fikir, 20 Teşrin-i Evvel 1926.

, “Cevab Yerine Dayak,” Hür Fikir, 20 Teşrini-Evvel 1926.

, “Cumhuriyet Bir Fazilet Sistemidir”, Hür Fikir, 2 Kanunu Sani 1928.

, “Cumhuriyete Sadik Taraftar Olabilirler mi?”, Hür Fikir, 9 Mart 1925.

, "Dualar Münasebetiyle”, Hür Fikir 26 Kanunu Sani 1925.

Ocak 1930. , "İnsanların Serencamlarından Garip Yiğidin Başına Neler Gelmez” Hür Fikir, 23 
Ocak 1930.

Nisan 1927.

, "İnsanların Serencamlarından Garip Yiğidin Başına Neler Gelmez” Hür Fikir, 25 Ocak 1930. , “İnsanların Serencamlarından Garip Yiğidin Başına Neler Gelmez Hür Fikir", 23 , "Karilerimle Yarenlik", Hür Fikir, 11 Mayıs 1925.

\footnotetext{
--------------, “Karilerimle Yarenlik”, Hür Fikir, 11 May1s 1925.

--------, “Layiklik İşte Bu Demektir”, Hür Fikir, 16 Nisan 1928.

-----------, "Manevi Amil” Hür Fikir, 18 May1s 1925;1)

-------------, “Muhammet 1”, Hür Fikir, 10 Nisan 1930.

"Muhammet 3" Hür Fikir, 24 Nisan 1930.

----------, “Reisicumhur”, Hür Fikir, 16 Mart 1925.
-----------, “Türkiye Cumhuriyeti ve Hür Fikir Beşer Yaşında”, Hür Fikir, 2 Kanunu Sani 1928.

Kutay, Cemal (1997), Atatürk'ün Beraberinde Götürdüğü Hasret: Türkçe İbadet, 3. B., İstanbul.

Mustafa Kemal (1993), Eskişehir-İzmit Konuşmalara1, Kaynak Yayınları, İstanbul.

Pekdoğan, Celal (1999), Batıcı Bir Düşünür Olarak Kılıçzade Hakkı (1872-1960), Hacettepe Üniversitesi Atatürk İlkeleri ve İnkılap Tarihi Enstitüsü, Yayınlanmamış Doktor Tezi, Ankara.

--------, (2002), “K1lıçzade Hakk1”, Diyanet İslam Ansiklopedisi, C. 25, s. 415-416.

Server Bedii, “İçtihadın Dördüncü Senesi”, İçtihad, 3 Nisan 1913.

Süleyman Nazif, Hür Fikir, 18 Nisan 1924.

Tunaya, Tarık Zafer (1996), Batılılaşma Hareketleri, 2. B., İstanbul, Arba Yayınları.

Türk Parlamento Tarihi (1996), TBMM III. Dönem 1927-1931, C.III, Ankara, TBMM Vakfı Yayınları.

Ülken, Hilmi Ziya (1992), Türkiye’de Çağdaş Düşünce Tarihi, Ülken Yayınları, İstanbul. 